Research Article

\title{
Spatiotemporal Rainfall Distribution of Soan River Basin, Pothwar Region, Pakistan
}

\author{
Fiaz Hussain, ${ }^{1,2}$ Ghulam Nabi, ${ }^{3}$ and Ray-Shyan Wu (iD ${ }^{1}$ \\ ${ }^{1}$ Department of Civil Engineering, National Central University, Chung-Li, Taiwan \\ ${ }^{2}$ Faculty of Agricultural Engineering and Technology, PMAS-Arid Agriculture University Rawalpindi, Rawalpindi, Pakistan \\ ${ }^{3}$ Centre of Excellence in Water Resources Engineering, University of Engineering and Technology, Lahore, Pakistan
}

Correspondence should be addressed to Ray-Shyan Wu; raywu@ncu.edu.tw

Received 4 November 2020; Accepted 20 January 2021; Published 8 February 2021

Academic Editor: Luis Gimeno

Copyright ( $\odot 2021$ Fiaz Hussain et al. This is an open access article distributed under the Creative Commons Attribution License, which permits unrestricted use, distribution, and reproduction in any medium, provided the original work is properly cited.

This study evaluates the spatiotemporal rainfall variability over the semimountainous Soan River Basin (SRB) of sub-Himalayan Pothwar region, Pakistan. The temporal rainfall trend analysis of sixteen rain gauges was performed on annual basis with longterm (1981-2016) data. The results depicted that there is substantial year-to-year and season-to-season variability in rainfall patterns, and rainfall patterns are generally erratic in nature. The results highlight that most of the highland rainfall stations showed decreasing trends on annual basis. The central and lowland stations of the study area recorded an increasing trend of rainfall except for Talagang station. The average annual rainfall of the study area ranges between $492 \mathrm{~mm}$ and $1710 \mathrm{~mm}$ in lowland and high-altitude areas, respectively. Of the whole year's rainfall, about 70 to $75 \%$ fall during the monsoon season. The rainfall spatial distribution maps obtained using the inverse distance weighting (IDW) method, through the GIS software, revealed the major rainfall range within the study area. There is a lack of water during postmonsoon months (November-February) and great differences in rainfall amounts between the mountainous areas and the lowlands. There is a need for the rational management of mountainous areas using mini and check dams to increase water production and stream regulation for lowland areas water availability. The spatiotemporal rainfall variability is crucial for better water resource management schemes in the study area of Pothwar region, Pakistan.

\section{Introduction}

Rainfall is the most important agroclimatic variable that determines the cropping system and overall agricultural productivity in rainfed areas of Pakistan. The changes in rainfall patterns are directly associated with climatic changes. The upward trend in the global mean temperature showed that more areas are warming than cooling. The linear increasing trend of global mean surface temperature approximately $1.0^{\circ} \mathrm{C}$ above preindustrial levels and likely to reach $1.5^{\circ} \mathrm{C}$ between 2030 and 2052 if continue to increase at the current rate [1] adversely affected the hydrometeorological process in continuous trends. Because of climate change, it has been also demonstrated that, in the middle of the $21^{\text {st }}$ century, the available water and average annual runoff will reduce up to $10-30 \%$ [2]. According to the Fifth
Assessment Report of the Intergovernmental Panel on Climate Change (IPCC), decreasing trends in precipitation and increasing trend in evapotranspiration result in droughts [2]. Rainfall is one of the dynamic components of the hydrological cycle, which generally varies in the spatial and temporal patterns due to climate change. The analysis of temporal and spatial variability of rainfall is important for hydrologists, agriculturalists, meteorologist, and industrialists in the aspect of sustainable utilization of water resources and control of floods and droughts [3]. The detailed knowledge of spatiotemporal rainfall distribution is crucial for accurate modeling of flood control using detention basins [4] or surface water storage using rainwater-harvesting systems [5]. These spatiotemporal changes in rainfall distribution directly influence the distribution of runoff and groundwater storage locally at spatial and temporal scales 
[6]. The spatial and temporal shift in rainfall patterns with changing climate directly affects water resources, agricultural divisions, and disaster management sectors. Therefore, it is important to detect the variation of trends at spatiotemporal scales around the world [7-10].

Pakistan is an agricultural country, having diverse, uneven, and arid to semiarid type of climate, and one of the most vulnerable to the effects of climate change. Due to nonfriendly environmental activities, the temperature variation of the country is increasing beyond its normal limits that create an optimistic impact on the production of the crop because of unreliable and unpredictable rainfall patterns. Climate scientists estimate that Pakistan's annual mean temperature has risen by roughly $0.5^{\circ} \mathrm{C}$ over the last 50 years and will rise by a further $3^{\circ} \mathrm{C}-6^{\circ} \mathrm{C}$ by the end of the century [11]. The water planning and utilization mostly depend on monsoonal rainfall, but the unpredictable and uneven distribution of rainfall both in time and in space cause floods in one part and drought in another part of the country. Projections by the Pakistan Meteorological Department (PMD) and Global Change Impact Studies Centre (GCISC) indicate that, by 2050 , the maximum rise in temperature will occur in the Northern Areas, central and southern Punjab, and southern Khyber Pakhtunkhwa (KP), and precipitation will increase in some regions and decrease in others [12]. Under future climate change scenarios, it is expected to experience increased variability of river flows due to increased variability of precipitation and the melting of glaciers [13]. Therefore, it is right to say rainfall is a crucial agroclimatological factor especially for arid and semiarid Northern areas and its analysis is an important prerequisite for agricultural water planning.

In view of the above, the present research deals with the study of rainfall patterns of Soan River Basin (SRB), the arid to subhumid region of Pothwar, Pakistan. However, there is no in-depth study of SRB rainfall climatology, its variability, and changing patterns using a long period data. In the present study, daily rainfall station data of SRB for the period 1981 to 2016 were analyzed with reference to temporal and spatial rainfall distribution. This study will be useful to the agriculture and water sectors of Pothwar area for better water management practices.

\section{Literature Review}

In the past few years, several studies have been conducted on spatiotemporal trends and its magnitude in hydrological (streamflow) and meteorological (rainfall, evapotranspiration, temperature, humidity, etc.) time-series data using parametric (simple linear regression) and nonparametric (Kendall rank correlation, Spearman's rho, Mann-Kendall, modified Mann-Kendall, and Theil-Sen's slope) tests throughout the world. For example, the studies reviewed to analyze the variability and spatiotemporal trend of precipitation and temperature in terms of the methodology adopted here are summarized in Table 1. The summary includes information about (i) study location and extent, i.e., country/region covering several catchments within a geographical coherent area, and river basins or catchments; (ii) hydrometeorological and climatic variables considered, i.e., precipitation, temperature $\left(T_{\max }, T_{\min }\right.$, and $\left.T_{\text {mean }}\right)$, evapotranspiration, relative humidity, and streamflow, including number of stations, temporal analysis resolution (monthly, seasonal, and annual), and length of time series included in the analysis, as variable; (iii) trend detection method(s) applied; (iv) summary of key findings, and (v) references. Trend analyses from 24 studies representing 13 countries around the world have been reviewed (Table 1). The review includes country-wise studies of precipitation and temperature from China, India, Pakistan, Iran, Bangladesh, Nepal, Vietnam, Turkey, Morocco, Italy, United States, Ethiopia, and Tanzania. In addition, these studies were selected based on the methodology used in this study for trend detection.

Through this review literature, it was observed that most of these studies performed the temporal trends (increasing or decreasing, significant or nonsignificant) of hydrometeorological time series data using parametric (simple linear regression) and nonparametric (Mann-Kendall test, modified Mann-Kendall test, and Sen's slope estimator). The most widely used at-site test is the Mann-Kendall test. The modified Mann-Kendall test is recommended for autocorrelated data. The magnitude of trend can be quantified using Sen's slope estimator, and if data are found to be autocorrelated, a prewhitening procedure can be applied to remove autocorrelation from the time series prior to applying the Mann-Kendall test. Moreover, the spatial pattern of trends was investigated in the ArcGIS environment using interpolation techniques such as inverse distance weighting (IDW) method and kriging.

Associated with global warming, there are strong indications that rainfall changes are already taking place on both the global [34-36] and regional scales [37-39]. The variability of rainfall has increased geographically, across seasons, and annually in Asia over the past few decades. In this context, the detection of historical variations in climate indicators is highly important for the countries where agriculture is the backbone of the economy, such as Pakistan, which is situated in one of the zones with a rapidly increasing temperature [40]. In recent studies, significant climatic changes have been documented in Pakistan, indicating that the $T_{\max }$ and $T_{\min }$ fluctuated at rates of $0.12-0.29$ and $0.10-0.37^{\circ} \mathrm{C} /$ decade, respectively $[41,42]$. Previous reports have indicated variations in temperature extremes in different parts of the country; for example, positive trends were observed in $T_{\max }$ and $T_{\min }$ in the upper, middle, and lower Indus basin [43], while decreasing (increasing) trends in $T_{\max }\left(T_{\min }\right)$ were observed in the northern part of the country [44]. Similarly, studies on trend assessments of precipitation have indicated increasing tendencies in annual precipitation for the northern, northeastern, and northwestern regions [45, 46]. Conversely, Reggiani et al. [47] reported an increase in temperature and a decrease in precipitation and corresponding river flows, starting from the late 1990s, for different subbasins in Upper Indus Basin. Furthermore, the central and southern parts of the country are mostly reported to have experienced a decreasing trend in annual precipitation $[48,49]$. Decreasing trends in rainfall 
TABle 1: Summary of reviewed studies on trend detection.

\begin{tabular}{|c|c|c|c|c|}
\hline Country/region & Data/variable & Methods & Key findings & Reference \\
\hline China & $\begin{array}{l}37 \text { stations' annual and } \\
\text { seasonal temperature and } \\
\text { precipitation (1960-2009) }\end{array}$ & $\begin{array}{l}\text { Linear regression, } \\
\text { Mann-Kendall test }\end{array}$ & $\begin{array}{l}\text { The mean annual temperature is } \\
\text { increasing with significant } \\
\text { warming trend in winter. Annual } \\
\text { precipitation showed a } \\
\text { nonsignificant decreasing trend in } \\
\text { which autumn is the most } \\
\text { significant. }\end{array}$ & Wang et al. [7] \\
\hline $\begin{array}{l}\text { China (Yangtze } \\
\text { River Basin) }\end{array}$ & $\begin{array}{l}214 \text { stations' seasonal and } \\
\text { annual temperature and } \\
\text { precipitation (1960-2015) }\end{array}$ & $\begin{array}{l}\text { Linear regression, } \\
\text { Mann-Kendall test, Sen's } \\
\text { slope estimator }\end{array}$ & $\begin{array}{l}\text { The seasonal and annual } T_{\max }, T_{\min } \\
\text { and } T_{\text {mean }} \text { temperatures increase } \\
\text { significantly. The annual } \\
\text { precipitation increases significantly } \\
\text { while the seasonal precipitation } \\
\text { significantly decreases. }\end{array}$ & Cui et al. [8] \\
\hline China(Jinan City) & $\begin{array}{l}\text { TRMM dataset seasonal and } \\
\text { annual precipitation } \\
(1979-2015)\end{array}$ & $\begin{array}{l}\text { Mann-Kendall trend, } \\
\text { Sen's slope estimator }\end{array}$ & $\begin{array}{l}\text { The increasing trend in annual } \\
\text { mean precipitation from the } \\
\text { northern plain to the southern } \\
\text { mountainous area. }\end{array}$ & Chang et al. [9] \\
\hline $\begin{array}{l}\text { India (Rajasthan } \\
\text { State) }\end{array}$ & $\begin{array}{l}33 \text { urban centers' seasonal and } \\
\text { annual rainfall and } \\
\text { temperature }(1971-2005)\end{array}$ & $\begin{array}{c}\text { Mann-Kendall test, Sen's } \\
\text { slope estimator }\end{array}$ & $\begin{array}{l}\text { Predominant changes in mean and } \\
\text { extreme rainfall and temperature } \\
\text { trends in most of the urban centers } \\
\text { of Rajasthan }\end{array}$ & Pingale et al. [10] \\
\hline $\begin{array}{l}\text { India (Uttarakhand } \\
\text { State) }\end{array}$ & $\begin{array}{c}13 \text { stations' monthly, seasonal, } \\
\text { and annual rainfall } \\
(1901-2015)\end{array}$ & $\begin{array}{l}\text { Mann-Kendall, modified } \\
\text { Mann-Kendall tests, } \\
\text { Theil-Sen's slope }\end{array}$ & $\begin{array}{l}\text { The significant positive and } \\
\text { negative trends were observed in } \\
\text { monthly, seasonal, and annual } \\
\text { rainfall time series in all } 13 \text { districts } \\
\text { of Uttarakhand state. }\end{array}$ & $\begin{array}{c}\text { Malik and Kumar } \\
{[14]}\end{array}$ \\
\hline $\begin{array}{l}\text { India (Godavari } \\
\text { River basin) }\end{array}$ & $\begin{array}{l}35 \text { stations' seasonal and } \\
\text { annual temperature } \\
(1964-2004)\end{array}$ & $\begin{array}{l}\text { Mann-Kendall test, } \\
\text { Theil-Sen's slope }\end{array}$ & $\begin{array}{l}\text { At seasonal time scales, a majority } \\
\text { of the stations exhibited no } \\
\text { significant trends in } T_{\text {mean }}, T_{\max } \text {, } \\
\text { and } T_{\min } \text { except postmonsoon for } \\
T_{\max } \text { and monsoon for } T_{\min } \text {. }\end{array}$ & Jhajharia et al. [15] \\
\hline $\begin{array}{l}\text { Iran (west, south, } \\
\text { and southwest) }\end{array}$ & $\begin{array}{l}13 \text { stations' annual } \\
\text { temperatures and rainfall } \\
\quad(1966-2005)\end{array}$ & $\begin{array}{c}\text { Mann-Kendall, } \\
\text { Mann-Whitney, and } \\
\text { Mann-Kendall rank tests }\end{array}$ & $\begin{array}{l}\text { Significant warming trend in } \\
\text { annual } T_{\text {mean }}, T_{\max } \text {, and } T_{\min } \text { at the } \\
\text { majority of the stations. No visible } \\
\text { trends were obtained for rainfall. }\end{array}$ & Tabari et al. [16] \\
\hline $\begin{array}{l}\text { Iran (north, } \\
\text { northwest, } \\
\text { southeast, and } \\
\text { central) }\end{array}$ & $\begin{array}{l}28 \text { stations' annual and } \\
\text { seasonal rainfall (1967-2006) }\end{array}$ & $\begin{array}{l}\text { Mann-Kendall test, } \\
\text { Theil-Sen's slope } \\
\text { estimator }\end{array}$ & $\begin{array}{l}\text { The significant negative trends in } \\
\text { the annual and seasonal (spring } \\
\text { and winter) rainfall time series } \\
\text { while summer and autumn seasons } \\
\text { showed positive trends. }\end{array}$ & Some'e et al. [17] \\
\hline $\begin{array}{l}\text { Iran (Urmia Lake } \\
\text { basin) }\end{array}$ & $\begin{array}{l}14 \text { stations' monthly and } \\
\text { annual evapotranspiration } \\
(1986-2010)\end{array}$ & $\begin{array}{l}\text { Modified Mann-Kendall } \\
\text { test, Theil-Sen's slope } \\
\text { estimator }\end{array}$ & $\begin{array}{l}\text { The results indicated an increasing } \\
\text { trend in ET values at all the } \\
\text { stations. }\end{array}$ & $\begin{array}{l}\text { Amirataee et al. } \\
{[18]}\end{array}$ \\
\hline
\end{tabular}

Overall, rainfall increased during the period 1948-2007, while the

Bangladesh (southwest coastal region)
8 stations' seasonal and annual Mann-Kendall test, Sen's trends intensified during the postrainfall (1948-2007) slope estimator 1990s. Postmonsoon and winter rainfall follow significant positive trends.

\section{Pakistan}

(Balochistan

province)
23 stations' seasonal and annual rainfall (1975-2010)
Mann-Kendall test
The negative trends in precipitation for both annual and seasonal scale for more than $70 \%$ of the stations in
Hossain et al. [19]

Ashraf et al. [20] 
TABle 1: Continued.

\begin{tabular}{lcc}
\hline Country/region & Data/variable & Methods \\
\hline Pakistan (Jhelum & $\begin{array}{c}\text { 21 stations' seasonal and } \\
\text { annual temperature, rainfall, } \\
\text { and streamflow (1961-2009) }\end{array}$ & $\begin{array}{c}\text { Mann-Kendall, Sen's } \\
\text { slope, and Linear } \\
\text { River basin) }\end{array}$
\end{tabular}
and streamflow (1961-2009) regression methods

, D

Maximum and minimum
temperatures showed increasin

trends while precipitation showed

nonsignificant increasing and

decreasing trends spread evenly

throughout the basin. In case of

streamflow, seasonal and annual

decreasing trends dominated in the

basin.

Pakistan (Chitral

2 stations' annual and seasonal temperature and precipitation

Mann-Kendall test, Sen's Decreasing and constant trends in the mean temperature and total precipitation, respectively.

The significant warming trend in annual $T_{\min }$ and $T_{\text {mean }}$ while $T_{\max }$ had insignificant variations except in the high elevation zone. The precipitation indicated the

Mahmood and Jia

$\begin{array}{ll}\text { Pakistan (Punjab } & \begin{array}{l}16 \text { stations' seasonal and } \\ \text { annual precipitation and } \\ \text { temperature (1967-2017) }\end{array}\end{array}$

Mann-Whitney, Mann-Kendall, and Sen's slope estimator

Ahmad et al. [22] cumulative increase in annual and autumn precipitation amounts at the zonal and regional level.

The onset of monsoon has shifted

$\begin{array}{ccc}35 \text { stations' monsoon rainfall } & \begin{array}{l}\text { Linear regression, } \\ \text { Pakistan }\end{array} \\ \text { homogeneity test }\end{array}$
towards earlier onset from the first week of July to the last week of June Ali et al. [24] at most of the stations of Pakistan.

The average precipitation trends in the basin are decreasing. The

Nepal (Karnali
River basin)
precipitation, and river flo (1981-2012)
Mann-Kendall test, Sen's increasing trends were observed in slope method

annual $T_{\text {min }}$ and $T_{\text {mean }}$ temperatures while $T_{\max }$ significant during the premonsoon season.

The outcome showed upward trends in the seasonal and annual rainfall over a period of 37 years, Phuong et al. [26] but only the dry season showed statistically significant trends.

Apparent decreasing trend in the winter rainfall whereas a general increasing trend is dominant in

97 stations' monthly, seasonal,

Turkey and annual rainfall (1930-2002)

Mann-Kendall test spring, summer, and autumn seasons. April, August, and

Türkeş et al. [27]

October months showed apparent increasing trends

\begin{tabular}{|c|c|c|c|c|}
\hline $\begin{array}{l}\text { Turkey (Ergene } \\
\text { drainage basin) }\end{array}$ & $\begin{array}{c}8 \text { stations' runoff, relative } \\
\text { humidity, temperature, } \\
\text { precipitation (1961 to 2010) }\end{array}$ & $\begin{array}{l}\text { Mann-Kendall test, } \\
\text { innovative Şen trend }\end{array}$ & $\begin{array}{c}\text { Test results showed a } \\
\text { nonsignificant trend almost in all } \\
\text { the cases }\end{array}$ & Dabanli et al. [28] \\
\hline $\begin{array}{l}\text { Morocco (Oum Er- } \\
\text { Rbia River basin) }\end{array}$ & $\begin{array}{l}15 \text { stations' annual and } \\
\text { seasonal rainfall (1970-2010) }\end{array}$ & Mann-Kendall test & $\begin{array}{l}\text { The results showed a general } \\
\text { decreasing tendency and the basin } \\
\text { tends towards drier conditions. }\end{array}$ & Ouatiki et al. [29] \\
\hline Italy (Southern). & $\begin{array}{l}129 \text { stations' monthly, } \\
\text { seasonal, and annual rainfall }\end{array}$ & $\begin{array}{l}\text { Mann-Kendall test, } \\
\text { innovative trend analysis }\end{array}$ & $\begin{array}{l}\text { Positive trends in seasonal and } \\
\text { annual rainfall, while negative } \\
\text { trends in winter and autumn } \\
\text { rainfall data over the study region. }\end{array}$ & Caloiero et al. [30] \\
\hline $\begin{array}{l}\text { United States } \\
\text { (Kentucky) }\end{array}$ & $\begin{array}{l}84 \text { stations' annual } \\
\text { precipitation and temperature } \\
(1950-2010)\end{array}$ & $\begin{array}{l}\text { Mann-Kendall test, } \\
\text { Theil-Sen's slope } \\
\text { estimator }\end{array}$ & $\begin{array}{l}\text { Significant positive trend in annual } \\
\text { series with a magnitude of } 4.1 \mathrm{~mm} / \\
\text { year in rainfall while } 0.01^{\circ} \mathrm{C} / \text { year in } \\
\text { mean temperature. }\end{array}$ & $\begin{array}{l}\text { Chattopadhyay } \\
\text { and Edwards [31] }\end{array}$ \\
\hline
\end{tabular}


TABle 1: Continued.

\begin{tabular}{|c|c|c|c|c|}
\hline Country/region & Data/variable & Methods & Key findings & Reference \\
\hline $\begin{array}{l}\text { Ethiopia (Tana } \\
\text { basin) }\end{array}$ & $\begin{array}{l}10 \text { stations' annual and } \\
\text { seasonal rainfall and } \\
\text { temperature (1980-2015) }\end{array}$ & $\begin{array}{l}\text { Mann-Kendall test, Sen's } \\
\text { slope estimator }\end{array}$ & $\begin{array}{l}\text { Results indicated that the amount } \\
\text { of rainfall decreased for the } \\
\text { majority of the stations while the } \\
T_{\text {mean }}, T_{\text {max }} \text {, and } T_{\min } \text { temperatures } \\
\text { have increased significantly for } \\
\text { most of the stations. }\end{array}$ & Birara et al. [32] \\
\hline $\begin{array}{l}\text { Tanzania } \\
\text { (Tanzanian Coast) }\end{array}$ & $\begin{array}{c}3 \text { stations' monthly, seasonal, } \\
\text { and annual rainfall } \\
(1953-2011)\end{array}$ & $\begin{array}{l}\text { Mann-Kendall test, Sen's } \\
\text { slope estimator }\end{array}$ & $\begin{array}{l}\text { The tests showed a negative trend at } \\
\text { a significance level of } \geq 95 \% \text {. }\end{array}$ & Kabanda [33] \\
\hline
\end{tabular}

patterns along with Pakistan's coastal areas and arid plains have been observed. The decreasing trend of rainfall is significant $(-1.18 \mathrm{~mm} /$ decade $)$ mainly from the north and northwest coastal areas whereas plain areas and southwest part have been observed with no significant trend [50]. Ali et al. [51] analyzed some significant trends of rainfall with disturbing patterns and heavy rainfall events in monsoon over selected regions of Pakistan. Safdar et al. [52] analyzed the extent of rainfall and temperature variations in Pakistan over the northern monsoon and observed a decrease in monsoon rainfall during the last two decades while a pronounced decrease was observed during 2010-2017, i.e., $17.58 \mathrm{~mm} /$ year accompanied by $0.18^{\circ} \mathrm{C}$ increase in temperature. Climate change has imposed rather negative impacts on the rainfall systems of Pakistan, mainly by demolishing the seasonal rainfalls or by modifying their intensity [53]. Studies conducted by the Pakistan Meteorological Department (PMD) have revealed that, in recent years, there has been a slow but steady change occurred in the location where major rainfalls concentrate. In the past, monsoon rains fell most intensely over Punjab but slowly and steadily, the concentration of rainfall has moved north and west to Khyber Pakhtunkhwa [54]. The average annual rainfall of Pothwar region varies from nearly $1500 \mathrm{~mm}$ at the northeast corner to $375 \mathrm{~mm}$ or less in the southwest [55]. Temporal and spatial rainfall variabilities are the basic problems of Soan Basin. The average annual rainfall in this area varies from $400 \mathrm{~mm}$ to $1710 \mathrm{~mm}$, the maximum in the north and minimum in the southwest $[56,57]$. However, no comprehensive research has been conducted regarding the spatiotemporal trends of precipitation in Soan River Basin (SRB), which is highly significant from the perspectives of rainfed agriculture, and the cropping system majorly depends upon rainfall. This study intends to bridge the knowledge gap through the use of more detailed and comprehensive research on the spatiotemporal variations in precipitation in SRB, Pothwar region, Pakistan. The primary goal of this work is to assess the spatial and temporal trends of precipitation and to analyze the trends and heterogeneity across the elevation gradient of the region. In addition, the spatial distribution of the annual and seasonal station trends, especially an analysis during the crop growing season (Rabi and Kharif), is presented.

\section{Material and Methods}

3.1. Description of the Study Area. Soan River Basin (SRB) stretches over an area of $9994 \mathrm{~km}^{2}$ within the elevation range of 222-2261 m above mean sea level (a.m.s.l.) in subHimalayan Pothwar region of Pakistan (Figure 1) [58]. The area falls under the administrative control of Attock, Rawalpindi, Islamabad, and Chakwal districts. The climate is continental, subtropical with hot summers and fairly cold winters under semiarid to subhumid climate zone. The lowest mean temperature is $9^{\circ} \mathrm{C}$ in December and the highest mean temperature is $31^{\circ} \mathrm{C}$ in June. The mean annual rainfall ranges between $400 \mathrm{~mm}$ in the plains and about $1710 \mathrm{~mm}$ in the mountainous terrain and about two-thirds of which occurs during the monsoon period (June-September). Agriculture is dependent on the rainfall and perennial flows stored through small/mini dams. The major crops grown under rainfed condition are wheat, chickpea, groundnut, millets, sorghum, oilseeds, and fodders. The land use analysis indicated that $10 \%$ area is agricultural land while mixed forest area is $8 \%$ of $9994 \mathrm{~km}^{2}$. Range and fallow land covered the maximum area (49\%) followed by mountainous land with shrubs and bushes (30\%). The residential area is $2 \%$ while water bodies are only $1 \%$. Soils are mostly noncalcareous of alluvial and loess plains, deep and varied in type, i.e., clay loam to silty clay loam with good drainage. The slope classification indicated that $52 \%$ of the area is flat to gentle $\left(<5^{\circ}\right.$ slope) while $22 \%$ of the area has a medium slope $\left(5^{\circ}-15^{\circ}\right)$. Steep $\left(15^{\circ}-30^{\circ}\right)$ and very steep slopes $\left(>30^{\circ}\right)$ cover about $19 \%$ and $7 \%$ of areas, respectively $[56,59]$. Overall, the northern part of the basin is dominated by humid and subhumid climates, while the central and southern parts are dominated by arid and semiarid climates, respectively. The northern boundary of SRB is surrounded by Margalla Hills and Murree Hills while the southern boundary is covered with salt range. The geographical locations of the available rain gauge stations located between the elevations ranges of 218-2025 m (a.m.s.l.) are shown in Figure 1 and Table 2. Based on the elevation range and locations of stations, the SRB is divided into three zones, i.e., zone- 1 consists of 5 stations (Murree, Kotli Sattian, Islamabad, NARC, and Rawalpindi) within 540-2025 m elevation range. Zone-2 consists of Fatehjang, 


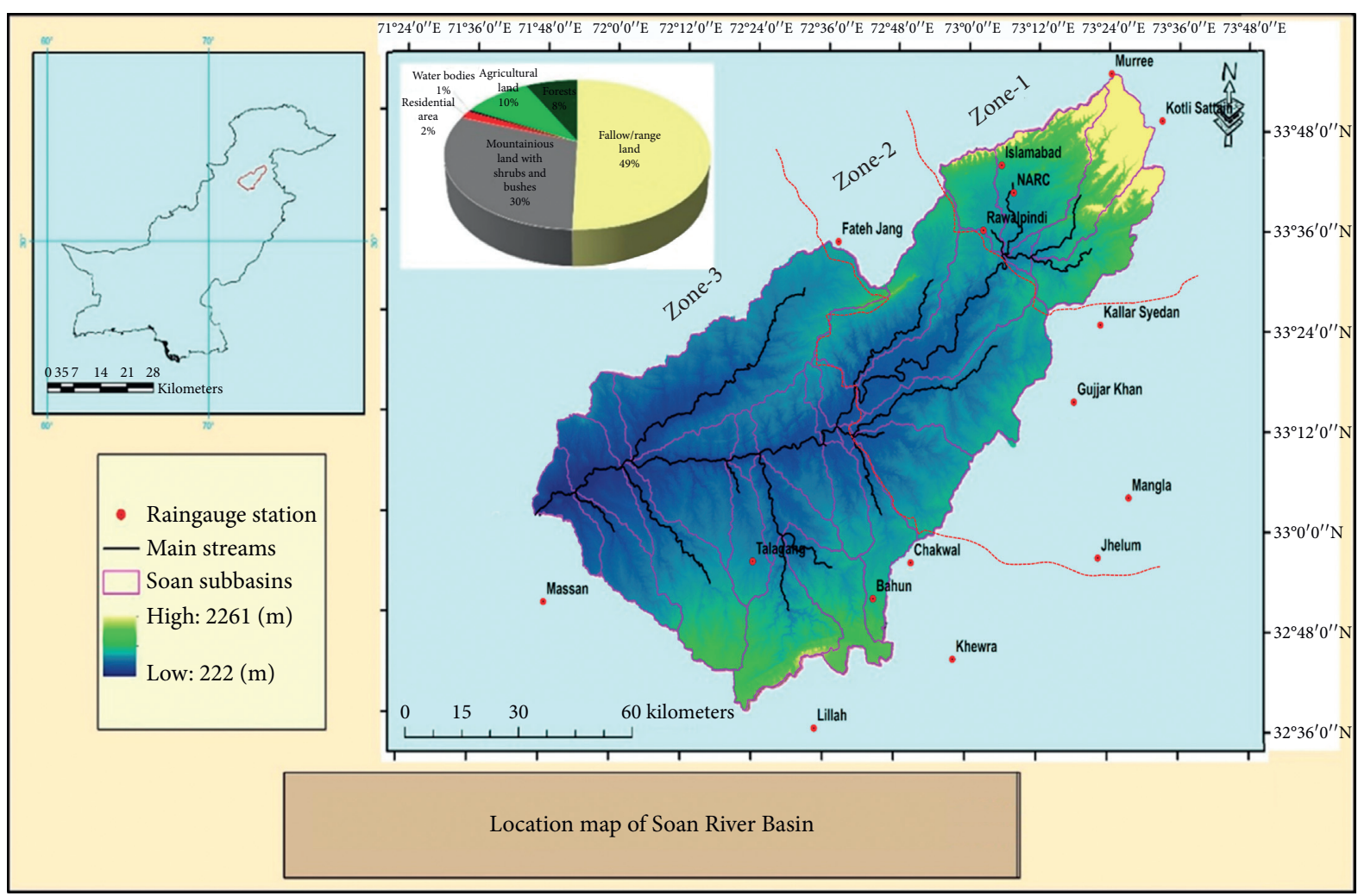

Figure 1: Location map of Soan River Basin, Pakistan: rain gauge stations, river and subbasins network, and elevation.

Kallar Syedan, Gujjar Khan, Mangla, and Jhelum stations within 283-529 m elevation range while zone-3 consists of 6 stations (Chakwal, Bahun, Talagang, Khewra, Lillah, and Massan) within 218-522 m elevation range. These zones are also categorized according to rainfall amount, i.e., heavy rainfall stations, medium rainfall stations, and less rainfall stations from zone-1 to zone-3, respectively. The detailed description of 16 rain gauge stations, data availability, and source of data is presented in Table 2.

\subsection{Data Acquisition and Processing. Long-term variations} at spatiotemporal scale of annual and seasonal rainfall ground data from 16 meteorological stations were statistically analyzed and investigated in the present study. The historical rainfall records based on daily and monthly time in SRB over the different periods according to data availability (Table 2) were collected from the Pakistan Meteorological Department (PMD), Surface Water Hydrology ProjectWAPDA (SWHP-WAPDA), and Soil and Water Conservation Research Institute (SAWCRI), Chakwal. These stations were selected based on their historical temporal coverage, homogeneity, and completeness of records. The daily data were further processed and converted into a monthly time series while the seasonal and annual records were obtained using the means of the monthly averages. The gaps in the data series were completed using the time-based interpolation method (monthly records were determined as the mean values of the same month for a period between \pm two years [60]. We designate four climatological seasons of a year: winter (December-February or DJF), spring or premonsoon (March-May or MAM), summer or monsoon (June-September or JJAS), and fall or postmonsoon (October-December or OND) based on Asmat et al. [61] and PMD recommendations. Two more seasons are investigated based on crop growing periods, Rabi (November-April) and Kharif (May-June) [62].

3.3. Methods. A trend is a significant change over time shown by a random variable, detectable by statistical parametric and nonparametric procedures while trend analysis of a time series data is the magnitude of trend and its statistical significance. In this study, statistical significance trend analysis was done using the nonparametric Mann-Kendall test (MK) while the magnitude of a linear trend was determined by nonparametric Sen's method [63]. These methods are selected because the MK test is suitable for cases where the trend may be assumed to be monotonic, and thus, no seasonal or other cycle is present in the data. Sen's method uses a linear model to estimate the slope of the trend and the variance of the residuals should be constant in time. Missing values are allowed and the data need not conform to any particular distribution. Besides, Sen's method is not greatly affected by single data errors or outliers. Before applying the Man$\mathrm{n}$-Kendall (MK) and Sen's slope techniques to detect the absolute change and trend in rainfall data series, the data were tested using a time serial autocorrelation technique. In addition, the autocorrelation was removed from the data series using the prewhitening method. Furthermore, trends were 
TABLE 2: Description of the meteorological stations.

\begin{tabular}{|c|c|c|c|c|c|c|}
\hline $\begin{array}{l}\text { Rain gauge } \\
\text { stations }\end{array}$ & Zone & Longitude & Latitude & Altitude (a m.s.l.) & Data range & Source of data \\
\hline Murree & Zone-1 & $73^{\circ} 24^{\prime} 3.148^{\prime \prime} \mathrm{E}$ & $33^{\circ} 54^{\prime} 58.847^{\prime \prime} \mathrm{N}$ & 2025 & $(1981-2016)$ & \multirow{7}{*}{ Pakistan Meteorological Department } \\
\hline Islamabad & Zone-1 & $73^{\circ} 5^{\prime} 42.464^{\prime \prime} \mathrm{E}$ & $33^{\circ} 43^{\prime} 50.202^{\prime \prime} \mathrm{N}$ & 569 & $(1981-2016)$ & \\
\hline Kotli Sattian & Zone-1 & $73^{\circ} 32^{\prime} 39.24^{\prime \prime} \mathrm{E}$ & $33^{\circ} 49^{\prime} 18.942^{\prime \prime} \mathrm{N}$ & 1352 & $(1981-2016)$ & \\
\hline Rawalpindi & Zone-1 & $73^{\circ} 2^{\prime} 50.035^{\prime \prime} \mathrm{E}$ & $33^{\circ} 35^{\prime} 41.506^{\prime \prime} \mathrm{N}$ & 540 & $(1976-2016)$ & \\
\hline Mangla & Zone-2 & $73^{\circ} 28^{\prime} 6.65^{\prime \prime} \mathrm{E}$ & $33^{\circ} 3^{\prime} 54.357^{\prime \prime} \mathrm{N}$ & 283 & $(1981-2016)$ & \\
\hline Jhelum & Zone-2 & $73^{\circ} 22^{\prime} 30.283^{\prime \prime} \mathrm{E}$ & $32^{\circ} 56^{\prime} 40.575^{\prime \prime} \mathrm{N}$ & 287 & $(1975-2016)$ & \\
\hline Chakwal & Zone-3 & $72^{\circ} 51^{\prime} 14.452^{\prime \prime} \mathrm{E}$ & $32^{\circ} 55^{\prime} 48.639^{\prime \prime} \mathrm{N}$ & 522 & $(1977-2016)$ & \\
\hline Kallar Syedan & Zone-2 & $73^{\circ} 22^{\prime} 17.085^{\prime \prime} \mathrm{E}$ & $33^{\circ} 24^{\prime} 41.95^{\prime \prime} \mathrm{N}$ & 529 & $(1981-2012)$ & \multirow{3}{*}{$\begin{array}{c}\text { WAPDA, Surface Water Hydrology } \\
\text { Project }\end{array}$} \\
\hline Gujjar Khan & Zone-2 & $73^{\circ} 18^{\prime} 14.396^{\prime \prime} \mathrm{E}$ & $33^{\circ} 15^{\prime} 24.645^{\prime \prime} \mathrm{N}$ & 458 & $(1981-2016)$ & \\
\hline Massan & Zone-3 & $71^{\circ} 49^{\prime} 26.733^{\prime \prime} \mathrm{E}$ & $32^{\circ} 49^{\prime} 39.852^{\prime \prime} \mathrm{N}$ & 335 & (1990-2015) & \\
\hline NARC & Zone-1 & $73^{\circ} 7^{\prime} 44.157^{\prime \prime} \mathrm{E}$ & $33^{\circ} 40^{\prime} 23.056^{\prime \prime} \mathrm{N}$ & 551 & $(1987-2012)$ & \multirow{6}{*}{$\begin{array}{c}\text { Soil and Water Conservation Research } \\
\text { Institute, Chakwal }\end{array}$} \\
\hline Fatehjang & Zone-2 & $72^{\circ} 38^{\prime} 14.979^{\prime \prime} \mathrm{E}$ & $33^{\circ} 33^{\prime} 58.479^{\prime \prime} \mathrm{N}$ & 514 & $(1987-2014)$ & \\
\hline Bahun & Zone-3 & $72^{\circ} 45^{\prime} 6.659^{\prime \prime} \mathrm{E}$ & $32^{\circ} 51^{\prime} 30.932^{\prime \prime} \mathrm{N}$ & 512 & (1984-2013) & \\
\hline Khewra & Zone-3 & $72^{\circ} 58^{\prime} 22.2^{\prime \prime} \mathrm{E}$ & $32^{\circ} 44^{\prime} 39.328^{\prime \prime} \mathrm{N}$ & 253 & (1984-2013) & \\
\hline Lillah & Zone-3 & $72^{\circ} 35^{\prime} 32.43^{\prime \prime} \mathrm{E}$ & $32^{\circ} 35^{\prime} 18.26^{\prime \prime} \mathrm{N}$ & 218 & (1984-2013) & \\
\hline Talagang & Zone-3 & $72^{\circ} 24^{\prime} 49.362^{\prime \prime} \mathrm{E}$ & $32^{\circ} 55^{\prime} 7.879^{\prime \prime} \mathrm{N}$ & 457 & $(1981-2016)$ & \\
\hline
\end{tabular}

analyzed using the Mann-Kendall and Sen's slope techniques to evaluate the patterns and their significance levels. Moreover, the inverse distance weighted (IDW) [64] (deterministic method) was incorporated as a spatial interpolation technique into the station data to analyze the spatial distribution of rainfall in SRB.

3.3.1. Time Serial Autocorrelation. The MK test requires time series data to be serially independent, if not it will show positive or negative trends when there is no trend. The probability of a significant trend would be added to the data series by the increased autocorrelation and would affect the results of the MK test [65]. The presence of significant autocorrelation should be checked and removed before applying the MK trend test [66]. Therefore, the following procedure was adopted before applying the MK trend test [67]. Compute the lag- 1 serial correlation coefficient $\left(r_{1}\right)$ of time series data as follows:

$$
r_{1}=\frac{1 / n-1 \sum_{i=1}^{n-1}\left(x_{i}-\bar{x}\right)\left(x_{i+1}-\bar{x}\right)}{1 / n \sum_{i=1}^{n}\left(x_{i}-\bar{x}\right)^{2}}
$$

where $r_{1}, x_{i}$, and $\bar{x}$ are the correlation coefficients at lag-1, rainfall data series, and mean of the rainfall time series, respectively.

If the condition $((-1-1.645 \sqrt{n-2}) /(n-2))$ $\leq r 1 \leq((-1+1.645 \sqrt{n-2}) /(n-2))$ is satisfied, then the data series is independent at the $10 \%$ significance level and the MK test can be applied to the original data series. Otherwise, the MK test should be applied after the removal of the significant autocorrelation, which can be computed as $x_{2}-r_{1} x_{1}, x_{3}-r_{1} x_{2}, \ldots, x_{n}-r_{1} x_{n-1}$.

3.3.2. Mann-Kendall Test (MK). MK test is a statistical method that is mostly used to check the null hypothesis of no trend versus the alternative hypothesis of the existence of monotonic increasing or decreasing trend of climatic time series data. The nonparametric Mann-Kendall test is fit for those data series where the trend may be assumed to be monotonic (i.e., mathematically the trend consistently increasing and never decreasing or consistently decreasing and never increasing) and no seasonal or other cycle is present $[68,69]$. The MK test has been widely used for the detection of trends in meteorological or hydrological temporal data series [70, 71]. The method is less sensitive to the abrupt breakpoints and is robust against outliers and missing values [72]. However, the test is sensitive to the serial correlation that may affect the test results [71, 73]. During the current study, the sequential correlation approach was employed before applying the MK test to examine the statistical significance of trends in the rainfall data series.

MK test performs two types of statistics depending upon the number of data values, i.e., $S$-statistics is used if the number of data values is less than 10 while $Z$-statistics is used if the number of data values is greater than or equal to 10 . The detailed procedure of the MK test is reported in $[68,69]$. If $x_{1}, x_{2}, x_{3}, \ldots, x_{n}$ is the time series of length $n$, then the MK test statistics $S$ is given as follows:

$$
S=\sum_{i=1}^{n-1} \sum_{j=i+1}^{n} \operatorname{sgn}\left(x_{j}-x_{i}\right)
$$

where $x_{j}$ and $x_{i}$ are the sequential values of data, $j>\underline{i}$, respectively, $n$ is the length of the series, and sgn $\left(x_{j}-x_{i}\right)$ is calculated using the following equation:

$$
\operatorname{sgn}\left(x_{j}-x_{i}\right)= \begin{cases}1, & \text { if } x_{j}-x_{i}>0 \\ 0, & \text { if } x_{j}-x_{i}=0 \\ -1 & \text { if } x_{j}-x_{i}<0\end{cases}
$$

A positive or negative value of $S$ indicates an upward (increasing) or a downward (decreasing) trend, respectively. If the number of data values is 10 or more, the $S$ statistic approximately behaves as normally distributed and the test is performed with normal distribution with the mean and variation as given below: 


$$
\begin{aligned}
E(S) & =0 \\
\operatorname{Var}(S) & =\frac{n(n-1)(2 n+5)-\sum_{i=1}^{m} t_{i}\left(t_{i}-1\right)\left(2 t_{i}+5\right)}{18},
\end{aligned}
$$

where $m$ is the number of tied (zero difference between compared values) groups and $t_{i}$ is the number of data points in the $i^{\text {th }}$ tied group. The normal distribution ( $Z$-statistic) is computed as follows:

$$
Z= \begin{cases}\frac{S-1}{\sqrt{\operatorname{Var}(S)},} & \text { if } S>0, \\ 0, & \text { if } S=0, \\ \frac{S+1}{\sqrt{\operatorname{Var}(S)},} & \text { if } S<0 .\end{cases}
$$

Statistically, the significance of the trend is assessed using $Z$-value. A positive value of $Z$ shows an upward (increasing) trend while the negative value indicates a downward (decreasing) trend. The $Z$-statistics follow the normal distribution with an average of zero and a variance of one with a null hypothesis of no trend [74]. In this study, the null hypothesis $\left(H_{0}\right)$ means there is no trend in the rainfall time series dataset while the alternate hypothesis $\left(H_{1}\right)$ means there exists an increasing or decreasing trend in the rainfall time series dataset. Generally, three levels of significance $(\alpha)$, i.e., $\alpha=0.1$ (10\%) with $Z= \pm 1.645, \alpha=0.05$ (5\%) with $Z= \pm 1.96$, and $\alpha=0.01$ (1\%) with $Z= \pm 2.33$ are globally used for testing the hypothesis, and we adopt the same in this study.

3.3.3. Sen's Slope Method. Sen's slope method is a nonparametric test used for predicting the magnitude (true slope) of hydrometeorological time series data [75]. Sen's slope estimator method uses a linear model for the trend analysis [76]. Sen's slope $\left(T_{i}\right)$ of all data pairs is calculated using the following equation:

$$
T_{i}=\frac{x_{j}-x_{k}}{j-k}, \quad \text { for } i=1,2,3, \ldots, n,
$$

where $x_{j}$ and $x_{k}$ are data values at time $j$ and $k(j>k)$ separately. The median of these $n$ values of $T_{i}$ is represented by Sen's slope of estimation (true slope) which is calculated using the following equation:

$$
Q_{i}= \begin{cases}T_{(n+1) / 2}, & \text { if } n \text { is odd, } \\ \frac{1}{2}\left(T_{n / 2}+T_{(n+2) / 2}\right), & \text { if } n \text { is even. }\end{cases}
$$

Sen's estimator $\left(Q_{\text {med }}\right)$ is calculated using the above equation depending upon the value of $n$ either odd or even and then $\left(Q_{\text {med }}\right)$ is computed using $100(1-\alpha) \%$ confidence interval using the nonparametric test depending upon normal distribution. A positive value of $Q_{i}$ indicates increasing (upward) trend while a negative value of $Q_{i}$ represents downward or decreasing trend of time series data.
3.3.4. Spatial Interpolation. The rainfall is highly unpredictable at a spatial scale, and to predict the areal trend of rainfall, the spatial analysis techniques are used based on fundamental geographic principle. The spatial analysis includes the behaviour of measured rainfall at different locations and the rainfall variation trend with observation points. The inverse distance weighted (IDW) spatial interpolation method was used for spatial trend analysis. IDW interpolation is one of the most commonly used deterministic methods and explicitly implements the assumption that things that are close to one another are more alike than those that are farther apart [64]. Many researchers have used this method for the spatial interpolation of data in different regions [77]. To predict a value for any unmeasured location, IDW used the measured values surrounding the prediction location. These measured values closest to the prediction location will have more influence on the predicted value than those farther away. Thus, IDW assumes that each measured point has a local influence that diminishes with distance. It weights the points closer to the prediction location greater than those do farther away.

The larger the power coefficient, the stronger the weight of nearby points as can be gleaned from the following equation that estimates the $z$ value at an unsampled location $j$ :

$$
\widehat{z}_{j}=\frac{\sum_{i}\left(z_{i} / d_{i j}^{n}\right)}{\sum_{i}\left(1 / d_{i j}^{n}\right)}
$$

The $\widehat{z}_{j}$ represents estimated value at $j$. The parameter $n$ is the weight parameter that is applied as an exponent to the distance, thus amplifying the irrelevance of a point at location $i$ as the distance to $j$ increases. Therefore, a large $n$ results in nearby points wielding a much greater influence on the unsampled location than a point further away resulting in an interpolated output. On the other hand, a very small value of $n$ will give all points within the search radius equal weight such that all unsampled locations will represent nothing more than the mean values of all sampled points within the search radius [64].

The geostatistical analysis tool of Arc Map 10.1 was used for mapping the spatial extent of rainfall distribution from point data on mean monthly, seasonal, and average annual trend analysis.

\section{Results and Discussion}

4.1. Rainfall Characteristics of Soan River Basin. The rainfall characteristics of rain gauge stations were analyzed based on mean monthly, seasonal, and annual rainfall patterns. The mean monthly rainfall trend of lowland and highland rain gauge stations is given in Figure 2. The variation of monthly rainfall showed that the intensity of rainfall gradually goes on increasing from May to August and then decreases sharply by October. August is the highest rainfall-recording month in all the stations. The monthly rainfall curves can be classified into three categories based on the maximum amount of rainfall and location of stations. The highland stations (Murree, Kotli Sattian, Islamabad, Rawalpindi, and 


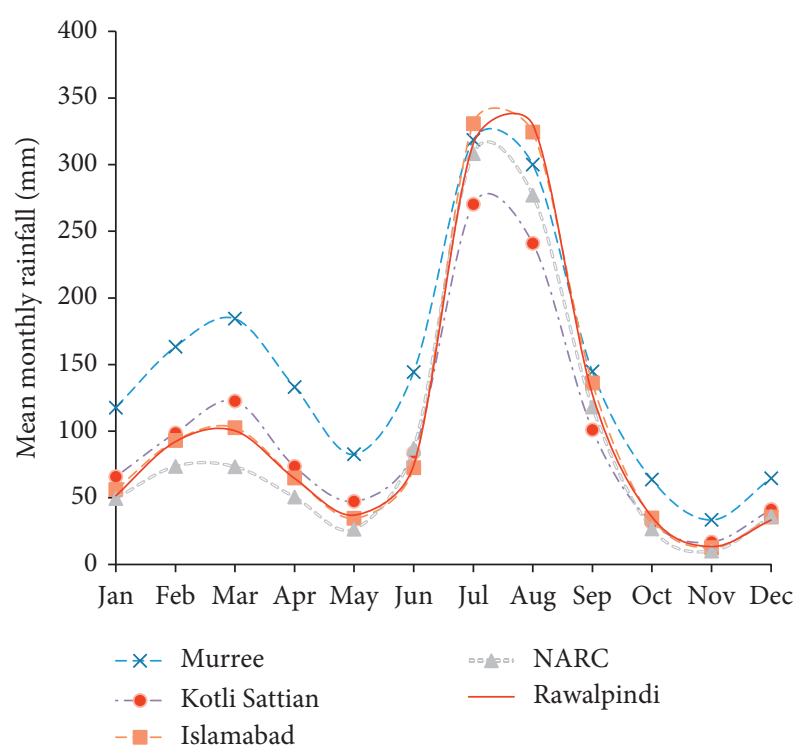

(a)

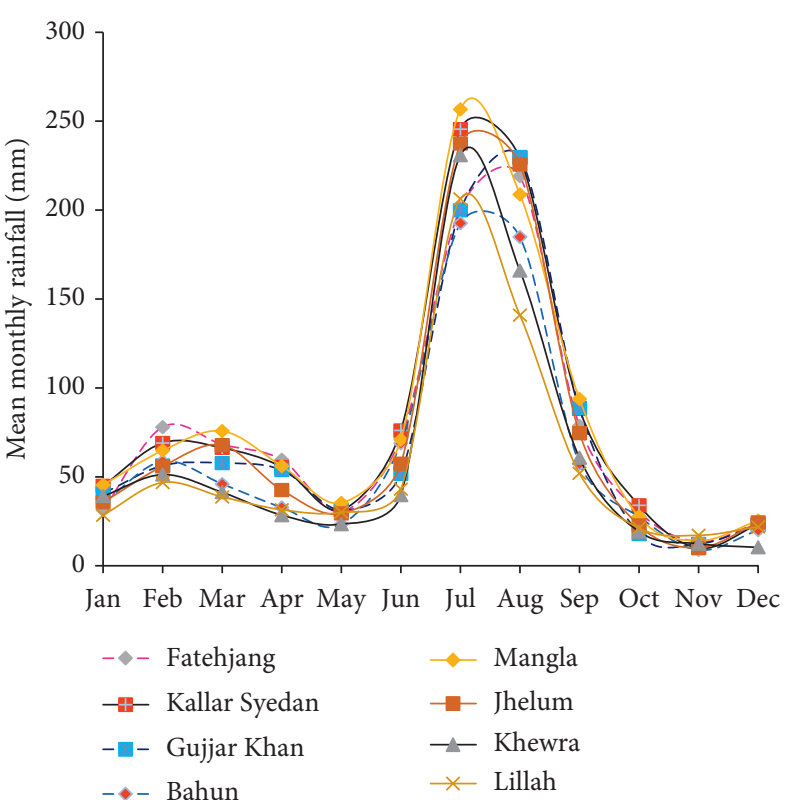

(b)

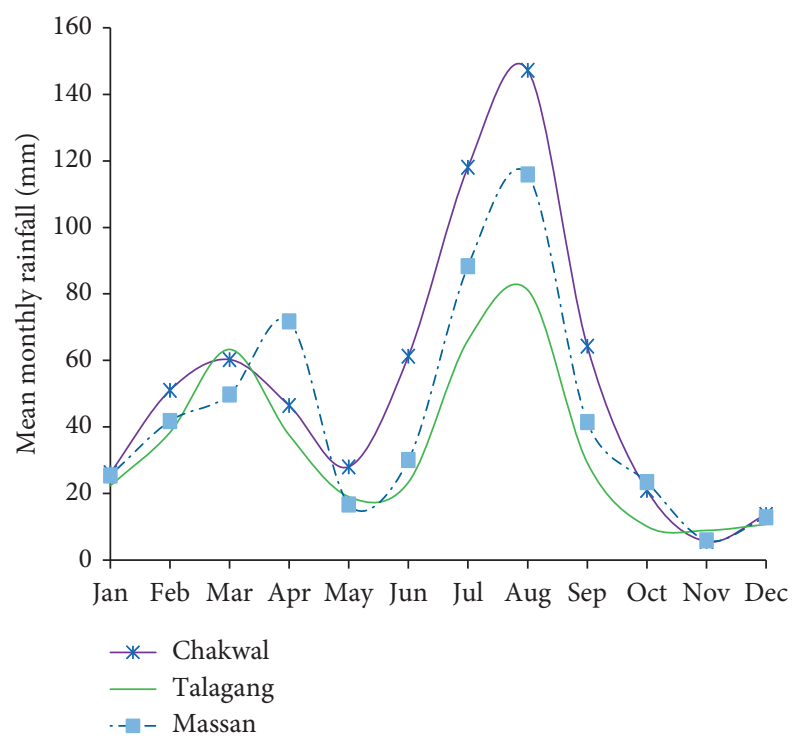

(c)

Figure 2: Mean monthly rainfall distribution of Soan River Basin. (a) Highland stations (Murree, Kotli Sattian, Islamabad, Rawalpindi, and NARC), (b) middle-land stations (Kallar Syedan, Gujjar Khan, Fatehjang, Mangla, Jhelum, Lillah, Khewra, and Bahun), and (c) lowlands stations (Chakwal, Talagang, and Massan).

NARC) are mountainous having a maximum rainfall range of $250 \mathrm{~mm}$ to $330 \mathrm{~mm}$. Middle-land stations, the second category (Kallar Syedan, Gujjar Khan, Fatehjang, Mangla, Jhelum, Lillah, Khewra, and Bahun), have $150 \mathrm{~mm}$ to $260 \mathrm{~mm}$ rainfall range and are located in relatively less heightened areas. The lowland stations (Chakwal, Talagang, and Massan) have a rainfall range of 50 to $150 \mathrm{~mm}$.

For a more detailed analysis of mean monthly rainfall distribution, the monthly data of each station were categorized into two parts, i.e., before and after the year 2000 as shown in Figure 3. This division of data into two parts provides in-depth variations of mean monthly rainfall amount before and after the year 2000; through this, we can analyze how the monthly rainfall shifts from dry to wet patterns and vice versa. It was observed that all the stations in zone-1 showed similar monthly rainfall distribution patterns except Kotli Sattian. There is a decreasing rainfall shift in March, April, July, and August months after the year 2000 and onward while June and September months are receiving more rainfall, indicating wetting situation. There is a monsoonal rainfall shift in high-altitude stations, indicating the drying situation; similarly, the premonsoon months (MAM) are also getting dry. These situations 

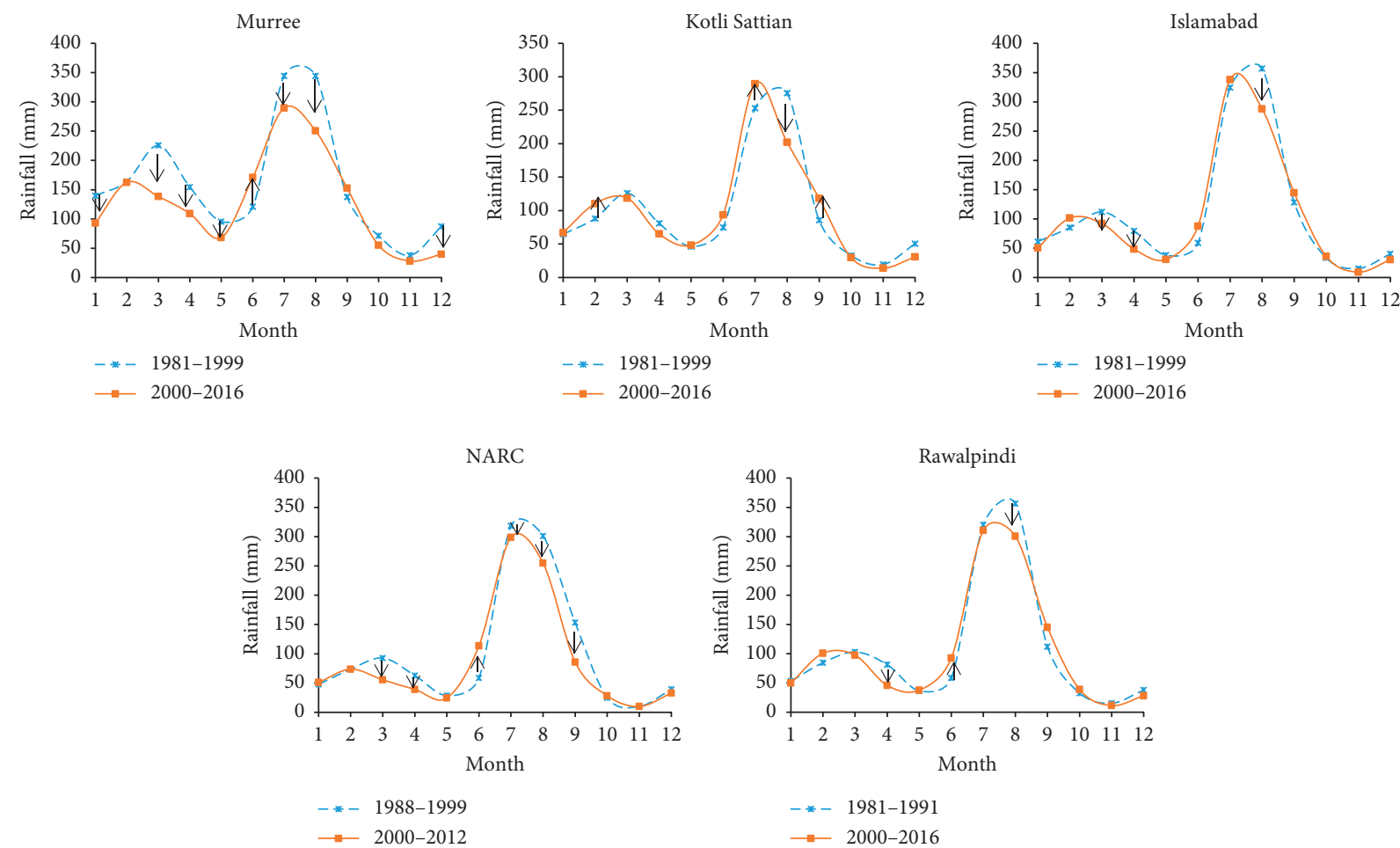

(a)
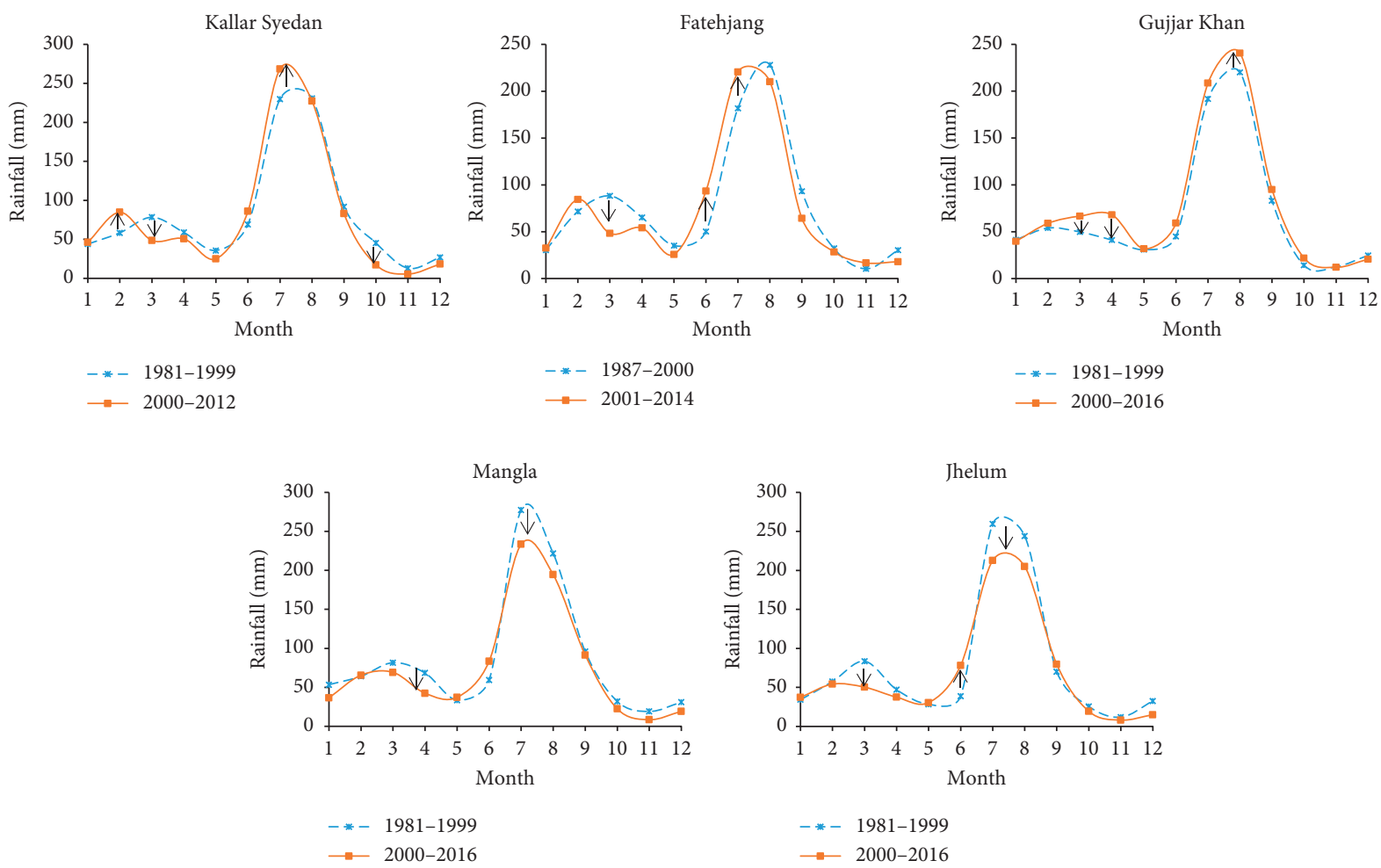

$\longrightarrow$ 2000-2016

(b)

Figure 3: Continued. 

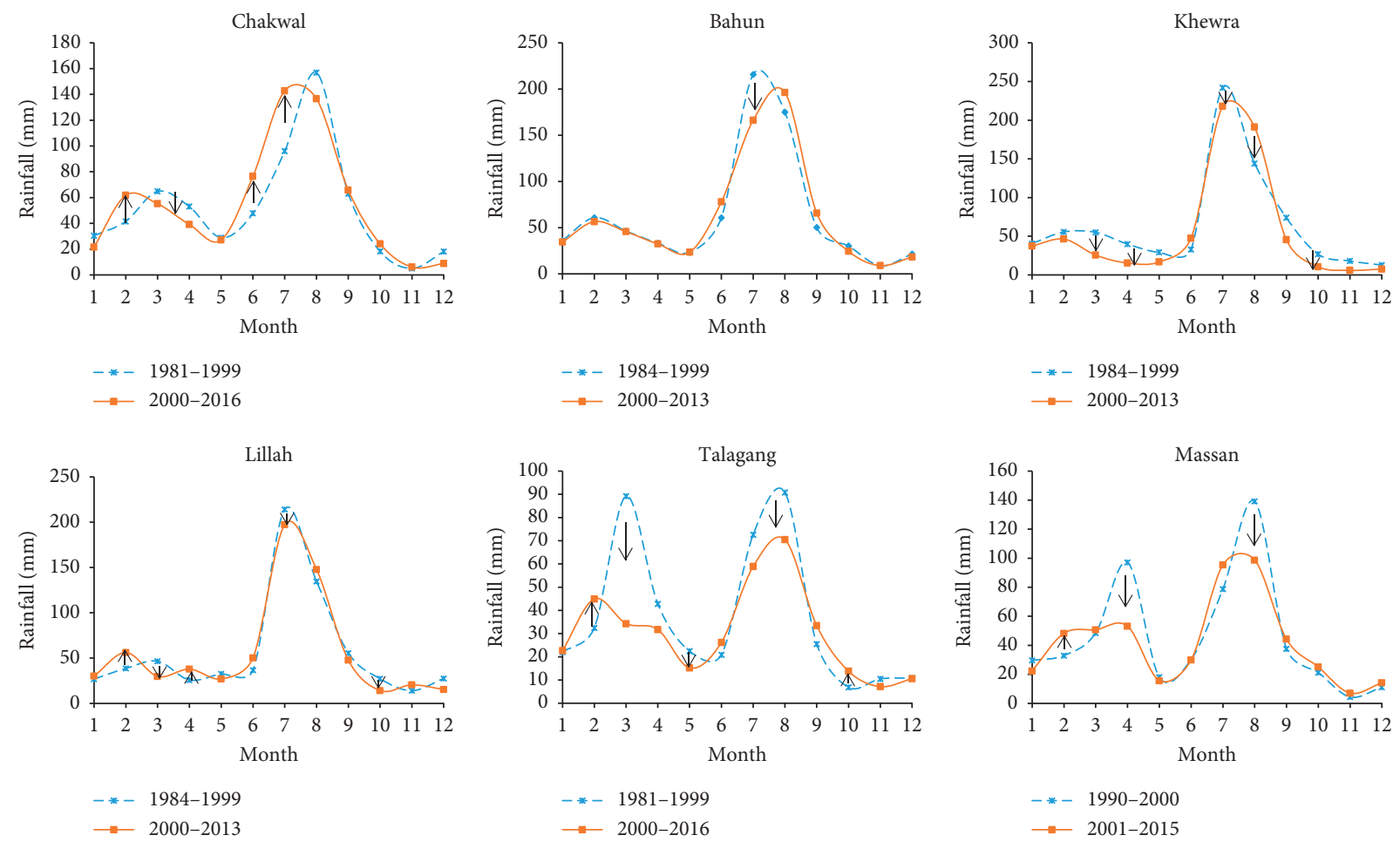

FIgURE 3: The shifting patterns of mean monthly rainfall distribution in (a) zone-1 (Murree, Kotli Sattian, Islamabad, Rawalpindi, and NARC), (b) zone-2 (Kallar Syedan, Gujjar Khan, Fatehjang, Mangla, and Jhelum), and (c) zone-3 (Chakwal, Bahun, Khewra, Lillah, Talagang, and Massan) rainfall stations.

indicate that there is a need for updating of cropping calendar according to rainfall distribution.

In zone-2, the monsoonal months (JJAS) of Fatehjang, Kallar Syedan, and Gujjar Khan stations are showing increasing shift while Mangla and Jhelum are showing decreasing shift while the premonsoon (MAM) months are showing drying situation in all the stations of zone-2. In zone-1, there are six stations. Chakwal and Bahun stations are showing similar kind of patterns; similarly, Talagang and Massan have similar monthly rainfall patterns. It was observed that there is a decreasing shift in monsoonal rainfall in all of zone-3 stations while the postmonsoon months (OND) are showing a wetting shift. The mean monthly shifting of rainfall (increasing and/or decreasing) situation from the first period (1981-1999) to the second period (2000-2016) indicates the wetting and drying situation, respectively, in all stations. Therefore, the cropping calendar should be shifted accordingly in SRB.

The mean seasonal rainfall comparison is given in Figure 4. The monsoon season consists of June to September months, and generally, these months have heavy rainfall spills. About 70 to $75 \%$ of rainfall occurs in the monsoon season while 25 to $30 \%$ of rainfall occurs in the rest of the monsoon season. Figure 5 depicts that five high-altitude stations (Murree, Kotli Sattian, Islamabad, NARC, and Rawalpindi) have heavy average rainfall $(>640 \mathrm{~mm})$ of the monsoon season. The medium-altitude stations (Fatehjang, Kallar Syedan, Gujjar Khan, Mangla, and Jhelum) have an average monsoon rainfall range of $570 \mathrm{~mm}$ to $639 \mathrm{~mm}$. The low-altitude stations such as Chakwal, Bahun, Khewra, Lillah, Talagang, and Massan have an average rainfall range of $200 \mathrm{~mm}$ to $504 \mathrm{~mm}$ of the monsoon season.

The comparison between the premonsoon season (March to May) and the postmonsoon season (October to December) indicated that premonsoon season has approximately $50 \%$ more rainfall in all stations as compared to postmonsoon. The Murree station has the highest average premonsoon $(400 \mathrm{~mm})$ and postmonsoon $(162 \mathrm{~mm})$ rainfall as compared to other stations.

The comparison of Rabi (November-April) and Kharif (May-October) seasons with rainfall distribution indicated that more/heavy rainfall occurs in Kharif season because of July, August, and September monsoonal months as compared to Rabi season which consists of less rainfall months such as November to April. Hilly rainfall stations have mean heavy rainfall of Kharif season greater than $960 \mathrm{~mm}$ to $1123 \mathrm{~mm}$ while lowland stations have less than $560 \mathrm{~mm}$ to $250 \mathrm{~mm}$ mean Kharif season rainfall. The Kharif rainfall is almost double than Rabi rainfall for all stations.

The comparison between monsoon rainfall and the rest of the monsoon season indicated that more rainfall occurs in the monsoon season as compared to the rest of the monsoon season. Most of the stations showed that 70 to $75 \%$ of rainfall occurred in the monsoon season while 25 to $30 \%$ of rainfall occurred in the rest of the monsoon season. However, some stations showed different patterns such as Murree and 


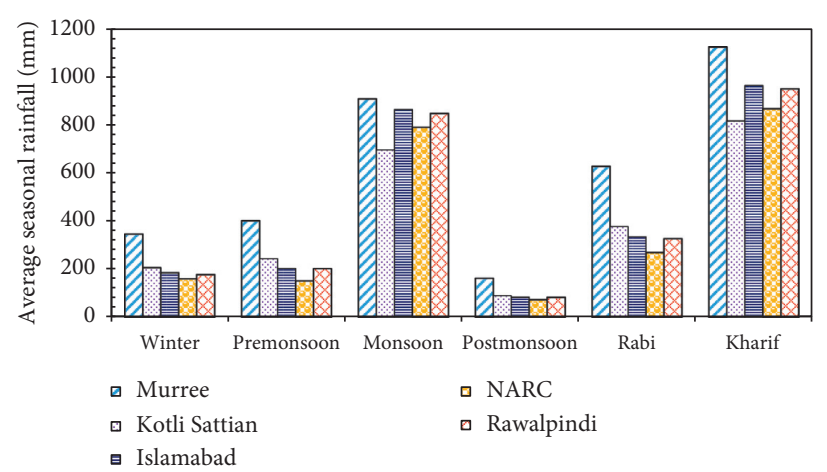

(a)

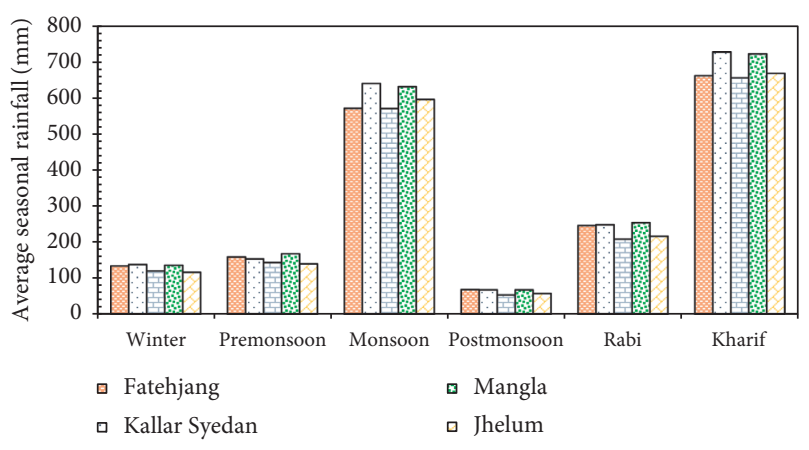

(b)

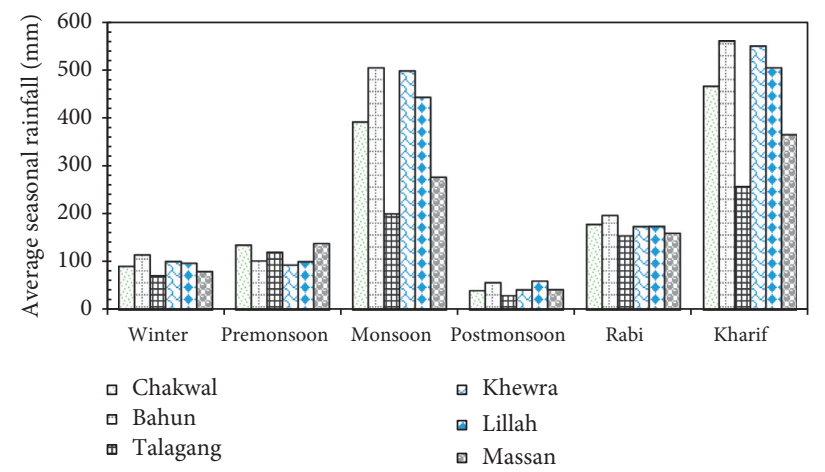

(c)

Figure 4: Mean seasonal (winter, premonsoon, monsoon, postmonsoon, Rabi, and Kharif) rainfall comparison of the study area in (a) zone1, (b) zone-2, and (c) zone-3, respectively.

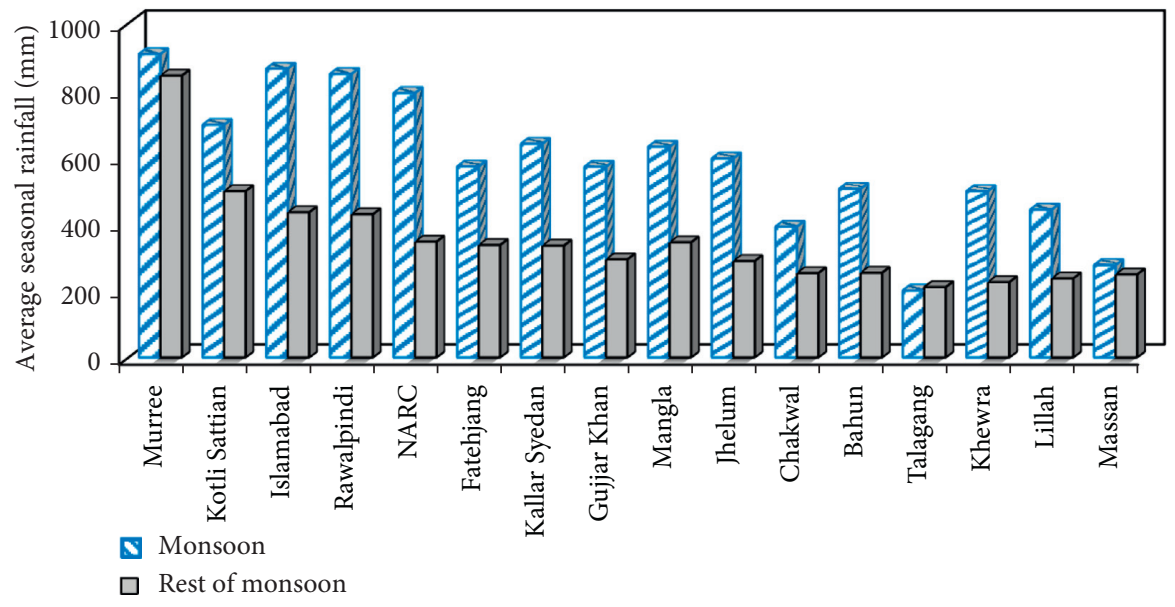

Figure 5: Monsoon and rest of monsoon rainfall comparison.

Massan stations have the almost same amount of rainfall in the monsoon and rest of the monsoon season while Talagang station has more rainfall in the rest of the monsoon season compared to monsoon season (Figure 5). This might be due to the following reasons: (i) the location of stations, i.e., Murree station is in high mountains comprising monsoon dominated part of Pakistan which receives the maximum amount of rainfall during the monsoon season and is characterized as very humid while Talagang and Massan stations are in southern plains and are almost arid due to less rainfall in monsoon, (ii) the earlier onset of monsoon in high mountain station (Murree) that receives rainfall from the currents transported from the Bay of Bengal that are later deflected by Himalayas and fall as precipitation in the northeast of Pakistan. According to the study by Ali et al. [24], there is a significant shift in monsoon onset in Murree station from 1971 to 2010 that may cause more rainfall in the rest of the monsoon season. (iii) Based on the monthly 
rainfall analysis, it is evident that all three stations have more rainfall in premonsoon (March, April, and May) season that may also cause the same amount of rainfall in the monsoon and rest of the monsoon seasons.

The average annual rainfall of 16 rain gauge stations of Soan River Basin is shown in Figure 6. It indicates that highaltitude areas (Murree, Kotli Sattian, Islamabad, NARC, and Rawalpindi) have heavy/highest rainfall as compared to lowland stations (Bahun, Chakwal, etc.). Depending upon this erratic rainfall pattern of Soan Basin, three categories of rainfall stations were made depending upon the topography and average annual rainfall amount.

(I) Heavy rainfall stations: these belong to zone-1 of highland stations (>540 m (a.m.s.l.)). There are five rainfall stations (Murree, Kotli Sattian, Islamabad, NARC, and Rawalpindi) in high-altitude area of Soan Basin. These stations have average annual rainfall greater than $1140 \mathrm{~mm}$ to $1750 \mathrm{~mm}$.

(II) Medium rainfall stations: these stations are located in zone-2 having an elevation range of $283-529 \mathrm{~m}$ (a.m.s.l.). These rainfall stations have rainfall greater than $860 \mathrm{~mm}$ and less than $975 \mathrm{~mm}$ which consists of Fatehjang, Kallar Syedan, Gujjar Khan, Mangla, and Jhelum.

(III) Less rainfall stations: Chakwal, Bahun, Khewra, Lillah, Talagang, and Massan stations are under this category (zone-3) having average annual rainfall less than $723 \mathrm{~mm}$.

Figure 6 also indicates that the Murree station has $1750 \mathrm{~mm}$ highest average annual rainfall while the Talagang station has the lowest $(410 \mathrm{~mm})$ rainfall of all the stations. The patterns of average annual rainfall followed the seasonal variations as during the winter months (DJF) rainfall occurrence is very less and goes on increasing by the end of May in premonsoon season. During the monsoon months from June to September, there is a substantial increase in the annual and seasonal rainfall with highest in July and August. With the advance of the postmonsoon season, the annual rainfall goes on decreasing.

4.2. Temporal Rainfall Trend Analysis of Soan Basin. In the present study, temporal rainfall trend analysis of SRB rain gauge stations was done using Mann-Kendall together with Sen's slope estimator on a monthly, seasonal, and yearly basis.

The variation in rainfall data on monthly basis was calculated individually for each month using the MK test, and the magnitude of the slope was calculated with Sen's slope estimator as represented in Tables 3-5. It was analyzed that there is a significant change in March, June, August, and September monthly rainfall data at $0.01,0.05$, and 0.1 levels of significance in zone-1 rainfall stations, i.e., some of the months showed an increasing (upward) trend and some showed decreasing trends. Five months (January, March, May, April, August, and December) in zone-1 stations showed negative values of $Z$ - and $Q$-statistics which represent decreasing trend while other months (February, June, and September) represent increasing trend as represented by
$Z$ - and Q-statistics in Table 3. March month of NARC while August month of Kotli Sattian and Murree stations showed a significantly decreasing trend at confidence levels 0.05, 0.01, and 0.1 , respectively. June and September months of Murree station indicated an increasing trend at significance levels 0.1 and 0.05 , respectively, while June month of NARC is also showing an increasing trend at 0.1 significance level. For zone-2 stations (Table 4), there are also significant and nonsignificant increasing and decreasing trend based on $Z$ and Q-statistics, for example, March month of Fatehjang, Kallar Syedan, and Jhelum stations showed a significantly decreasing trend at 0.05 and 0.1 significant levels, respectively, while June month of Gujjar Khan and Mangla stations showed a significant increasing trend at same confidence levels, respectively. July and August months of Jhelum station also showed a decreasing trend at the 0.1 significance level. For zone-3 stations (Table 5), for example, February and June months of Chakwal station showed a significant increasing trend at 0.01 and 0.05 level of confidence, respectively. Similarly, July month of Massan and September month of Talagang showed a significant increasing trend at 0.1 and 0.01 significant levels, respectively. March month of all stations in zone-3 except Massan showed a decreasing trend while Khewra, Lillah, and Talagang stations showed significant decreasing trends at 0.01 and 0.1 significant levels. Generally, it was observed that March and August month of most stations in all zones showed a significant decreasing trend based on the MK test statistic while June month showed an increasing trend. December month of most stations showed nonsignificant decreasing trend while February month showed an increasing trend.

Seasonal variations of rainfall trends based on the MK test indicated the wide variability of precipitation in the SRB as shown in Tables 3-5. The seasonal variations have been observed in six seasons based on rainfall amount and cropping calendar. In winter precipitation, the negative trends were more obvious over zone-1 station, particularly in the Murree station. The negative trend in the winter season correlates with the findings of Salma et al. [50], who reported a decreasing trend of precipitation in different areas of Pakistan. The maximum decline in winter precipitation was observed at the high-altitude Murree station in zone-1. The decreasing trend of this station was significant at the 0.1 confidence level. The obtained results correlate with the findings of Nawaz et al. [23], who reported a maximum decreasing trend of winter precipitation at the Murree station. Similarly, the premonsoon season of all zone-1 stations showed a decreasing trend while a prominent decrease was observed at Murree station at 0.1 significant level. The postmonsoon season also showed a decreasing trend in all stations of zone-1. Most stations in zone-1 except Murree revealed insignificant signs of negative slopes during the winter, premonsoon, and postmonsoon seasons. Monsoon precipitation of Murree and Kotli Sattian showed an insignificant increasing trend while Islamabad, NARC, and Rawalpindi showed an insignificant decreasing trend. In addition, the precipitation trends during the crop growing seasons (Rabi and Kharif) indicated nonsignificant decreasing trends in most stations except Kotli Sattian for 


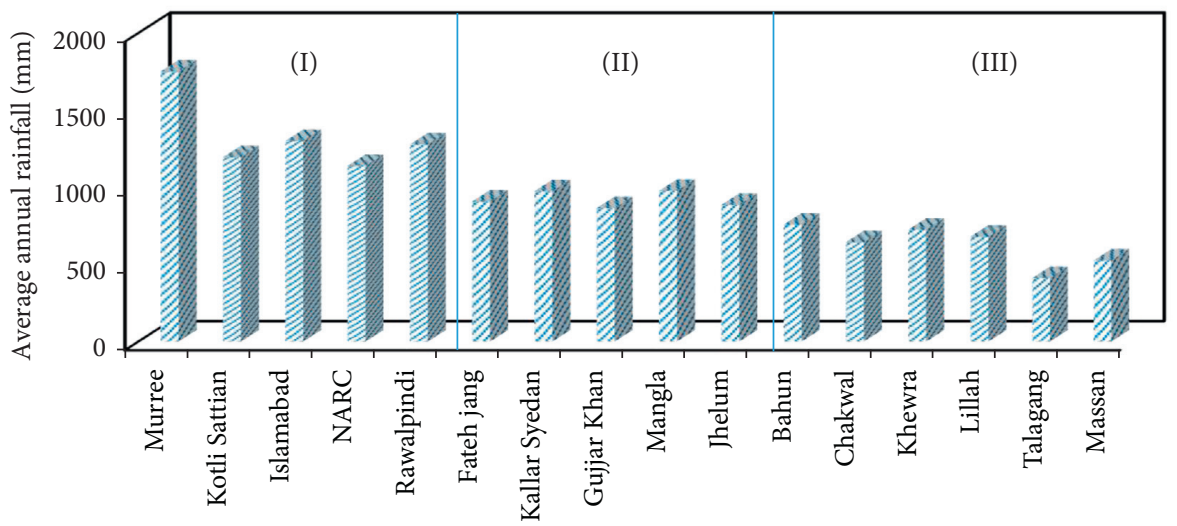

Figure 6: Average annual rainfall comparison of study area stations where classifications (I), (III), and (III) represent (a) zone-1 heavy rainfall stations, (b) zone-2 medium rainfall stations, and (c) zone-3 less rainfall stations, respectively.

TABLE 3: Monthly, seasonal, and annual rainfall statistic in zone-1 stations using Mann-Kendall test and Sen's slope estimate.

\begin{tabular}{lccccccccccc}
\hline \multirow{2}{*}{ Time series } & \multicolumn{2}{c}{ Murree } & \multicolumn{2}{c}{ Kotli Sattian } & \multicolumn{2}{c}{ Islamabad } & \multicolumn{2}{c}{ NARC } & \multicolumn{2}{c}{ Rawalpindi } \\
& Test $Z$ & $Q$ & Test $Z$ & $Q$ & Test $Z$ & $Q$ & Test $Z$ & $Q$ & Test $Z$ \\
\hline JAN & -1.59 & -1.728 & 0.05 & 0.051 & -0.53 & -0.432 & -0.19 & 0.312 & -1.15 & -0.618 \\
FEB & 0.29 & 0.585 & 0.67 & 0.486 & 0.72 & 0.868 & 0.63 & 0.211 & 0.71 & 0.590 \\
MAR & -1.51 & -3.335 & -0.67 & -0.873 & -1.16 & -1.245 & $-\mathbf{2 . 1 3}$ & -2.519 & -0.93 & -0.876 \\
APR & -0.53 & -0.616 & -0.60 & -0.468 & -1.25 & -1.006 & 0.54 & -0.120 & -0.60 & -0.341 \\
MAY & -1.12 & -0.831 & 0.16 & 0.050 & -0.05 & -0.034 & 0.47 & -0.735 & 0.54 & 0.167 \\
JUN & $\mathbf{1 . 7 6}^{+}$ & 1.52 & 1.12 & 0.809 & 1.06 & 0.900 & $\mathbf{1 . 8 5}^{+}$ & 1.873 & 0.43 & 0.268 \\
JUL & -0.4 & -0.767 & 0.53 & 0.892 & 0.38 & 1.063 & -0.30 & 1.966 & 0.04 & 0.183 \\
AUG & $-\mathbf{1 . 9 2}^{+}$ & -4.23 & $-\mathbf{2 . 6 3} *$ & -4.189 & -1.05 & -2.342 & 0.07 & 0.855 & -1.00 & -1.605 \\
SEP & $\mathbf{2 . 0 6}$ & 2.176 & 1.53 & 1.311 & 0.69 & 0.959 & -1.05 & -0.904 & 0.79 & 0.809 \\
OCT & -0.64 & -0.418 & -0.16 & -0.044 & 0.31 & 0.102 & 0.59 & 0.000 & -0.25 & -0.077 \\
NOV & -0.04 & -0.004 & 0.05 & 0.000 & 0.27 & 0.022 & 1.24 & 0.268 & -0.68 & -0.091 \\
DEC & -1.42 & -0.979 & -1.09 & -0.253 & -0.82 & -0.222 & -0.54 & -0.538 & -0.47 & -0.038 \\
Annual (J-D) & $-\mathbf{1 . 8 9}^{+}$ & -9.812 & 0.122 & 0.539 & -0.10 & -0.453 & -0.30 & 2.640 & -0.24 & -1.317 \\
Rabi (O-M) & $-\mathbf{2 . 2 5}^{*}$ & -7.484 & 0.50 & 0.911 & -0.44 & -1.190 & -0.63 & -2.183 & -0.17 & -0.527 \\
Kharif (A-S) & -0.83 & -3.131 & 0.095 & 0.230 & -0.20 & -1.458 & -0.44 & 3.714 & -0.30 & -1.800 \\
Winter (DJF) & $-\mathbf{2 . 0 3}^{+}$ & -4.718 & -0.18 & -0.215 & -0.26 & -0.243 & -0.02 & 0.596 & -0.02 & -0.019 \\
Premonsoon (MAM) & $-\mathbf{1 . 8 4}^{+}$ & -4.458 & -0.50 & -0.850 & -1.29 & -2.498 & -0.54 & -2.042 & -0.36 & -0.406 \\
Monsoon (JJAS) & 0.07 & 0.165 & 0.068 & 0.259 & -0.37 & -1.568 & -0.07 & 4.047 & -0.38 & -1.150 \\
Postmonsoon (OND) & -1.59 & -2.609 & -1.17 & -1.234 & -0.80 & -0.953 & -0.26 & -0.404 & -0.57 & -0.455 \\
\hline
\end{tabular}

Values in bold showed a significant trend with Mann-Kendall (MK) test at three different confidence levels, i.e., ${ }^{* *}$ represents trend at $\alpha=0.01$ level of significance, ${ }^{*}$ represents trend at $\alpha=0.05$ level of significance, and ${ }^{+}$represents trend at $\alpha=0.1$ level of significance. Negative sign of $Z$ and $Q$ test represents decreasing trend while positive sign represents increasing trend.

TABLE 4: Monthly, seasonal, and annual rainfall statistic in zone-2 stations using Mann-Kendall test and Sen's slope estimate.

\begin{tabular}{lccccccccccc}
\hline \multirow{2}{*}{ Time series } & \multicolumn{2}{c}{ Fatehjang } & \multicolumn{2}{c}{ Kallar Syedan } & \multicolumn{2}{c}{ Gujjar Khan } & \multicolumn{2}{c}{ Mangla } & \multicolumn{2}{c}{ Jhelum } \\
& Test $Z$ & $Q$ & Test $Z$ & $Q$ & Test $Z$ & $Q$ & Test $Z$ & $Q$ & Test $Z$ & $Q$ \\
\hline JAN & 0.83 & 0.312 & 0.00 & 0.000 & -0.27 & -0.107 & 0.91 & 0.069 & 1.09 & 0.578 \\
FEB & 0.12 & 0.211 & 1.56 & 1.450 & 0.65 & 0.444 & $\mathbf{2 . 7 8 ^ { * * }}$ & 0.987 & 0.25 & 0.167 \\
MAR & $-\mathbf{2 . 3 1 ^ { * }}$ & -2.519 & $-\mathbf{1 . 8 3 ^ { + }}$ & -1.343 & 0.90 & 0.401 & -0.29 & -0.198 & -0.61 & -0.442 \\
APR & -0.14 & -0.120 & -0.13 & -0.148 & 0.63 & 0.383 & 0.44 & 0.191 & 0.23 & 0.067 \\
MAY & -1.50 & -0.735 & -0.45 & -0.166 & 0.29 & 0.092 & 0.99 & 0.256 & 0.30 & 0.136 \\
JUN & 1.54 & 1.873 & 1.18 & 1.635 & $\mathbf{2 . 4 4}$ & 1.368 & $\mathbf{2 . 2 7 ^ { * }}$ & 1.189 & 0.89 & 0.717 \\
JUL & 0.87 & 1.966 & 1.49 & 3.241 & 0.74 & 0.840 & 1.34 & 1.298 & -1.28 & -1.885 \\
AUG & 0.53 & 0.855 & -0.06 & -0.081 & 0.19 & 0.295 & 1.01 & 1.121 & 1.48 & 3.000 \\
SEP & -1.07 & -0.904 & -0.91 & -0.624 & 0.42 & 0.326 & 0.16 & 0.081 & 1.28 & 1.100 \\
OCT & 0.28 & 0.000 & -0.07 & 0.000 & 0.93 & 0.248 & 0.72 & 0.146 & 0.11 & 0.000 \\
NOV & 1.49 & 0.268 & -1.25 & -0.181 & -1.36 & -0.174 & 0.27 & 0.000 & -0.18 & 0.000 \\
DEC & -1.37 & -0.538 & -0.47 & 0.000 & 0.38 & 0.005 & -1.06 & 0.000 & -1.47 & -0.450 \\
\hline
\end{tabular}


TABLE 4: Continued.

\begin{tabular}{lcccccccccc}
\hline \multirow{2}{*}{ Time series } & \multicolumn{2}{c}{ Fatehjang } & \multicolumn{2}{c}{ Kallar Syedan } & \multicolumn{2}{c}{ Gujjar Khan } & \multicolumn{2}{c}{ Mangla } \\
& Test $Z$ & $Q$ & Test $Z$ & $Q$ & Test $Z$ & $Q$ & Test $Z$ & $Q$ & Test $Z$ & $Q$ \\
\hline Annual (J-D) & 0.49 & 2.640 & 0.78 & 3.312 & 1.40 & 5.191 & $\mathbf{1 . 8 6}^{+}$ & 5.035 & 0.75 & 2.986 \\
Rabi (O-M) & -1.05 & -2.183 & -0.55 & -0.643 & 0.56 & 0.490 & 1.57 & 1.672 & -0.68 & -0.671 \\
Kharif (A-S) & 0.73 & 3.714 & 1.49 & 5.005 & $\mathbf{1 . 6 9}^{+}$ & 4.960 & 1.18 & 3.188 & 0.64 & 1.572 \\
Winter (DJF) & 0.28 & 0.596 & 0.86 & 1.065 & -0.03 & -0.021 & $\mathbf{1 . 8 3}^{+}$ & 1.183 & 0.20 & 0.321 \\
Premonsoon (MAM) & -1.48 & -2.042 & -1.23 & -1.325 & $\mathbf{1 . 6 8}^{+}$ & 1.139 & 0.21 & 0.18 & -0.11 & -0.088 \\
Monsoon (JJAS) & 1.09 & 4.047 & $\mathbf{1 . 7 6}$ & 4.387 & 1.17 & 3.422 & 1.64 & 3.114 & 0.96 & 3.000 \\
Postmonsoon (OND) & -0.43 & -0.404 & -0.71 & -0.509 & 0.30 & 0.215 & 0.3 & 0.118 & -1.32 & -0.763 \\
\hline
\end{tabular}

Values in bold showed a significant trend with Mann-Kendall (MK) test at three different confidence levels, i.e., ${ }^{* *}$ represents trend at $\alpha=0.01$ level of significance, ${ }^{*}$ represents trend at $\alpha=0.05$ level of significance, and ${ }^{+}$represents trend at $\alpha=0.1$ level of significance. Negative sign of $Z$ and $Q$ test represents decreasing trend while positive sign represents increasing trend.

TABLE 5: Monthly, seasonal, and annual rainfall statistic in zone-3 stations using Mann-Kendall test and Sen's slope estimate.

\begin{tabular}{|c|c|c|c|c|c|c|c|c|c|c|c|c|}
\hline \multirow{2}{*}{ Time series } & \multicolumn{2}{|c|}{ Chakwal } & \multicolumn{2}{|c|}{ Bahun } & \multicolumn{2}{|c|}{ Khewra } & \multicolumn{2}{|c|}{ Lillah } & \multicolumn{2}{|c|}{ Talagang } & \multicolumn{2}{|c|}{ Massan } \\
\hline & Test $Z$ & $Q$ & Test $Z$ & $Q$ & Test $Z$ & $Q$ & Test $Z$ & $Q$ & Test $Z$ & $Q$ & Test $Z$ & Q \\
\hline JAN & 0.91 & 0.069 & 1.09 & 0.578 & 0.20 & 0.021 & 0.48 & 0.167 & -0.52 & -0.025 & -1.05 & -0.318 \\
\hline FEB & $2.78^{* *}$ & 0.987 & 0.25 & 0.167 & -0.16 & -0.106 & 0.79 & 0.750 & -0.40 & -0.114 & 0.24 & 0.135 \\
\hline MAR & -0.29 & -0.198 & -0.61 & -0.442 & $-2.61^{* *}$ & -1.439 & $-1.84^{+}$ & -1.354 & $-2.80^{* *}$ & -2.283 & 0.022 & 0.017 \\
\hline APR & 0.44 & 0.191 & 0.23 & 0.067 & -0.92 & -0.250 & 0.93 & 0.480 & -1.34 & -0.494 & -0.04 & -0.218 \\
\hline MAY & 0.99 & 0.256 & 0.30 & 0. & -1.00 & -0.2 & -0.13 & 0.000 & -0.16 & 0.000 & -0.29 & -0.038 \\
\hline JUN & $2.27^{*}$ & 1.189 & 0.89 & 0.717 & 0.68 & 0.445 & 1.04 & 0.545 & 1.27 & 0.288 & 0.15 & 0.000 \\
\hline JUL & 1.34 & 1.298 & -1.28 & -1.885 & 0.16 & 0.650 & -0.27 & -0.340 & -0.27 & -0.094 & $1.72^{+}$ & 2.095 \\
\hline AUG & 1.01 & 1.121 & 1.48 & 3.000 & 1.28 & & 0.48 & 0.626 & -0.11 & -0 & -1.04 & -1.900 \\
\hline SEP & 0.16 & 0.081 & 1.28 & 1. & 0.50 & 0.5 & -1.09 & -0.738 & $2.62^{* *}$ & 0.803 & 0.31 & 0.269 \\
\hline OCT & 0.72 & 0.146 & 0.11 & 0.000 & -1.14 & -0.269 & $-2.77^{* *}$ & -0.846 & 0.38 & 0.000 & 1.32 & 0.600 \\
\hline $\mathrm{NOV}$ & 0.27 & 0.000 & -0.18 & 0.000 & -1.10 & 0.000 & 1.15 & 0.385 & -0.33 & 0.000 & 0.43 & 0.000 \\
\hline DEC & -1.06 & 0.000 & -1.47 & -0.450 & -1.16 & 0.000 & -1.56 & -0.500 & 0.22 & 0.000 & -0.60 & -0.067 \\
\hline Annua & $1.86^{+}$ & 5.035 & 0.75 & 2.986 & -0.61 & -1.683 & 0.61 & 1.007 & -1.38 & -2.976 & 0.26 & 2.311 \\
\hline Rabi (O-M) & 1.57 & 1.672 & -0.68 & -0.671 & -1.34 & -2.098 & -0.48 & -0.635 & $-2.084^{*}$ & -2.266 & 0.57 & 1.280 \\
\hline Kharif (A-S) & 1.18 & 3.188 & 0.64 & 1.572 & 0.71 & 1.438 & 0.07 & 0.117 & -0.01 & -0.065 & 0.04 & 0.547 \\
\hline Winter (DJF) & $1.83^{+}$ & 1.183 & 0.20 & 0.321 & 0.12 & 0.202 & 0.79 & 0.835 & 0.03 & 0.012 & 0.26 & 0.230 \\
\hline Premonsoon (MAM) & 0.21 & 0.18 & -0.11 & -0.088 & $-2.57^{*}$ & -2.633 & -0.77 & -1.000 & $-2.75^{* *}$ & -2.797 & -0.35 & -1.240 \\
\hline Monso & 1.64 & 3.114 & 0.96 & 3.000 & 1.36 & 3.164 & -0.11 & -0.063 & 0.19 & 0.264 & 0.31 & 1.071 \\
\hline Postmonsoon (OND) & 0.3 & 0.118 & -1.32 & -0.763 & -1.39 & -0.909 & -1.36 & -1.190 & 0.18 & 0.029 & 0.99 & 1.121 \\
\hline
\end{tabular}

Values in bold showed a significant trend with Mann-Kendall (MK) test at three different confidence levels, i.e., ${ }^{* *}$ represents trend at $\alpha=0.01$ level of significance, ${ }^{*}$ represents trend at $\alpha=0.05$ level of significance, and ${ }^{+}$represents trend at $\alpha=0.1$ level of significance. Negative sign of $Z$ and $Q$ test represents decreasing trend while positive sign represents increasing trend.

zone-1, while Murree station showed a significant decrease at 0.05 confidence level during the Rabi season. The winter and monsoon seasons precipitation of all stations except Jhelum showed an increasing trend in zone- 2 while monsoon precipitation of Kallar Syedan showed a significant increasing trend, and on the other hand, Jhelum showed a significantly decreasing trend at 0.1 confidence level. The pre- and postmonsoon precipitation of all stations except Gujjar Khan showed insignificant decreasing trend while Gujjar Khan premonsoon precipitation showed a significant increasing trend at 0.1 level of significance. Rabi season rainfall in zone-2 stations showed insignificant negative (decrease) slope of the trend while Kharif season showed an increasing (positive) trend except for Jhelum station. The increasing trend was prominent in Gujjar Khan station while Jhelum showed a negative trend at 0.1 confidence level during Kharif season. The monsoon season rainfall in zone-3 stations showed an insignificant increasing trend except for
Lillah station that showed decreasing trend while the winter precipitation also showed increasing trends in all stations of zone- 3 and Chakwal station showed a significant increasing trend of winter precipitation at 0.1 level of confidence (Table 5). Pre- and postmonsoon precipitation of most stations in zone-3 showed decreasing trend and it was observed that Khewra and Talagang premonsoon rainfall showed significant decreasing trends at 0.05 and 0.01 levels of confidence, respectively. Rabi season rainfall showed a decreasing trend in all stations of zone- 3 except Bahun and Massan and it was observed that Talagang showed a prominent decreasing trend during Rabi season with 0.05 confidence level. Kharif season precipitation showed an insignificant increasing trend in all stations of zone-3 except Talagang. Generally speaking, it was observed that the winter rainfall in high-altitude stations is decreasing while in lowland stations it is increasing while monsoonal rainfall trend is in increasing situation in SRB. Most stations in SRB 
showed a decreasing trend of precipitation during premonsoon and postmonsoon seasons. Rabi season rainfall is decreasing while Kharif season rainfall trend is increasing in SRB. Overall, the results indicate an increase in rainfall amount at low-elevation stations whereas a decrease in the amount of precipitation was noticed for higher-elevation stations.

The annual time series and trends of rainfall for each zone in SRB are presented in Figure 7. The division of increasing and decreasing trend of all stations based on $Z$ - and $Q$-statistics of annual rainfall time series (Tables 3-5) was performed. There are sixteen stations; half of the stations' rainfall showed a decreasing trend (Figure 7 ). The annual average precipitation showed a slight increasing trend in the other eight stations during the study period 1981-2016. The year-to-year variation in rainfall gives an idea about the changes in rainfall patterns over the regime. This helps for better water management and proper irrigation to cropping. In addition, the annual precipitation trends and magnitude for the Soan River Basin obtained by the MK test and the Sen's slope method are presented in Table 3.

The results of the MK test indicated the wide variability of precipitation for the annual time scales in the majority of stations during the period 1981-2016. The annual rainfall revealed a significant increasing trend in Chakwal station, with a magnitude of $1.86 \mathrm{~mm} /$ year while Murree $(-1.89 \mathrm{~mm}$ / year) and Jhelum $(-1.84 \mathrm{~mm} /$ year $)$ stations showed a significantly decreasing trend at 0.1 level of significance. Overall, the annual station trends showed that most sites were characterized by nonsignificant positive and negative trends. It was analyzed that a decreasing trend was detected for the high-altitude stations in zone-1 such as Murree, Islamabad, NARC, and Rawalpindi, with a value average value of $-6.5 \mathrm{~mm} /$ decade, in zone-1. However, positive tendencies were observed at low elevation in zone- 2 and zone-3 stations, for example, Chakwal, Bahun, Kallar Syedan, and Gujjar Khan stations showed an increase at rates of $18.6,7.5,7.8$, and $14.0 \mathrm{~mm} /$ decade, respectively. Overall, the results indicate an increase in the precipitation amount at low-elevation stations, whereas a decrease in the amount of precipitation was noticed for higher-elevation stations. A decrease in precipitation for higher elevation was also reported by Reggiani et al. [47] in Upper Indus Basin. The outcomes of this study regarding the increase in amounts of precipitation for lower-elevation regions are consistent with the findings reported in $[78,79]$. The results of decreasing trend of precipitation at annual scale at a higher elevation and particular results of Murree station are associated with findings reported in $[80,81]$, which reported a decreasing trend in annual precipitation from lower to higher elevation. The possible explanation of decreasing precipitation at higher elevation could be linked with the decrease in cloud cover and soil moisture and, ultimately, increase in daytime and decrease in nighttime temperatures ( $T_{\max }$ and $T_{\min }$ ) $[82,83]$. However, an in-depth investigation is required to explore, in detail, the quantitative relationship between precipitation and temperature indices and to learn about the main driving factors for such asymmetric trends of precipitation for SRB, which is a highly worthwhile region with respect to the agriculture and economy of Pakistan.
4.3. Spatial Rainfall Distribution Analysis. The average monthly, seasonal, and annual rainfall spatial analysis was done using the IDW interpolation method as shown in Figure 8. The spatial distribution of monthly, seasonal, and annual rainfall indicated that the rainfall pattern of Soan Basin is erratic and there is great variation in rainfall aerially from high-altitude to low-altitude stations individually. The erraticism of rainfall was estimated by classifying the average monthly, seasonal, and annual rainfall distribution into three categories. The first class is named as upper range class (zone1 ), and in this range, the highest maximum rainfall occurred for monthly, seasonal, and annual distribution. This class consists of Murree, Kotli Sattian, Islamabad, NARC, and Rawalpindi stations. The second class is called lower range having the lowest rainfall for monthly, seasonal, and annual rainfall data in Chakwal, Talagang, and Massan stations. The third category is the medium rainfall range having Fatehjang, Kallar Syedan, Gujjar Khan, Mangla, Jhelum, Bahun, Khewra, and Lillah stations. The IDW interpolation method gives reasonable results in spatial rainfall mapping in the study area. The spatial variability in rainfall is extremely high (Figure 8). The results of spatial distribution maps indicated a wide range of rainfalls for all monthly, seasonal, and annual bases through the basin where many different zones of rainfalls could be recognized. These maps are easy to understand according to interest and are reliable and useful for agricultural water management and various stakeholders.

The spatial distribution of winter rainfall showed that most stations revealed insignificant signs of positive and negative slopes during the winter season. Most of the winter precipitation was due to western disturbances, and consequently, most stations in the study area indicated less precipitation. The premonsoon spatial distribution indicated variable fluctuations for most stations while the spatial distribution of the station trends during the monsoon season indicated an insignificant increasing trend over the entire study area. According to the MK analysis results, 11 stations showed positive trends, while five stations revealed negative tendencies. The spatial distribution of station trends during postmonsoon indicated that 11 out of 16 stations showed negative trends. Spatial distribution of rainfall during Kharif season shows that highland areas in the north of the study area receive $706-1030 \mathrm{~mm}$ of rainfall while most of the central portion of the study area receives $513-706 \mathrm{~mm}$ of rainfall. The southwestern section of the study area is the lowland area which receives rainfall between 331 and $513 \mathrm{~mm}$ and some scattered portions of the western part receive rainfall between 185 and $331 \mathrm{~mm}$ (Figure 8(b)). The Kharif season rainfall amount is much higher in comparison with Rabi season. Furthermore, the station precipitation indicated that the magnitude of the positive trend in Kharif was more pronounced than in the Rabi season. From Figure 8(b), it was observed that the Rabi season only receives a slight amount of rainfall compared to Kharif season and the highest amount of rainfall that is received in the study area is 90 to $675 \mathrm{~mm}$. Moreover, the spatial distribution of precipitation trends during the crop growing seasons (Rabi and Kharif) indicated considerable fluctuations at most stations. 


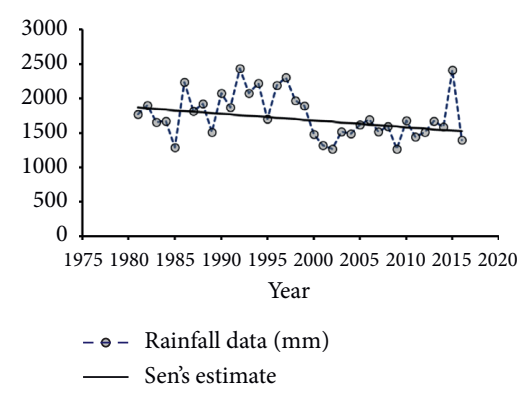

Murree

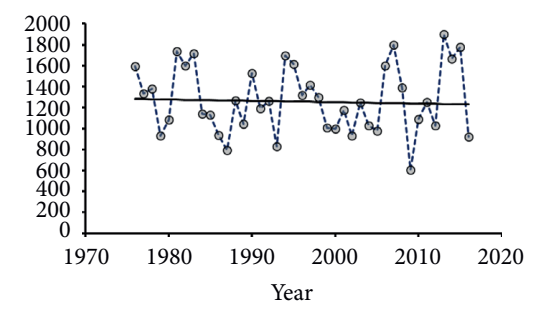

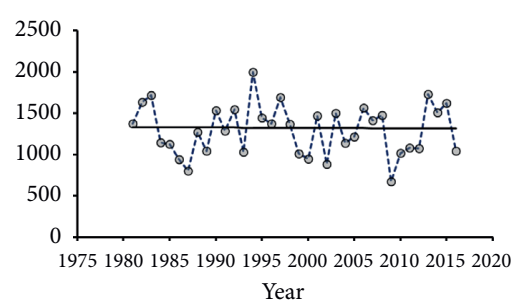

- $\bullet$ - Rainfall data (mm)

- Sen's estimate

Islamabad

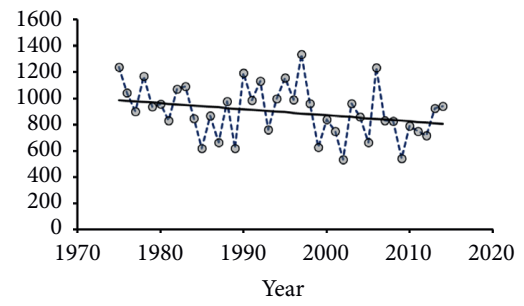

- $\bullet$ - Rainfall data (mm)

_- Sen's estimate

Mangla

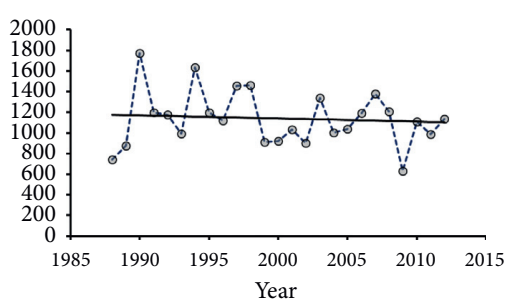

- $\bullet$ - Rainfall data (mm)

- Sen's estimate

NARC

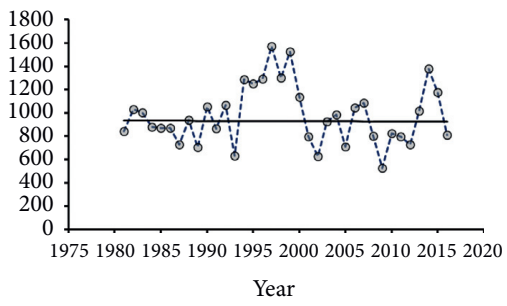

- - Rainfall data (mm)

_ Sen's estimate

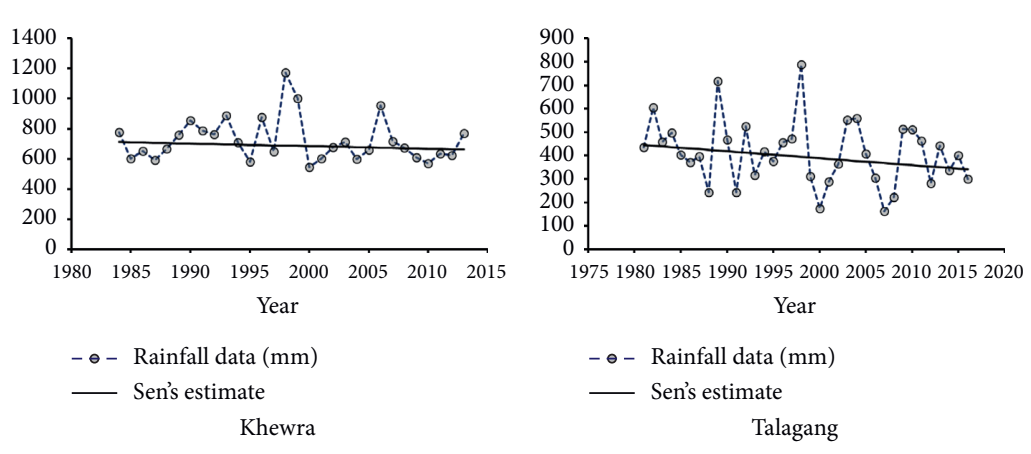

(a)

Figure 7: Continued. 

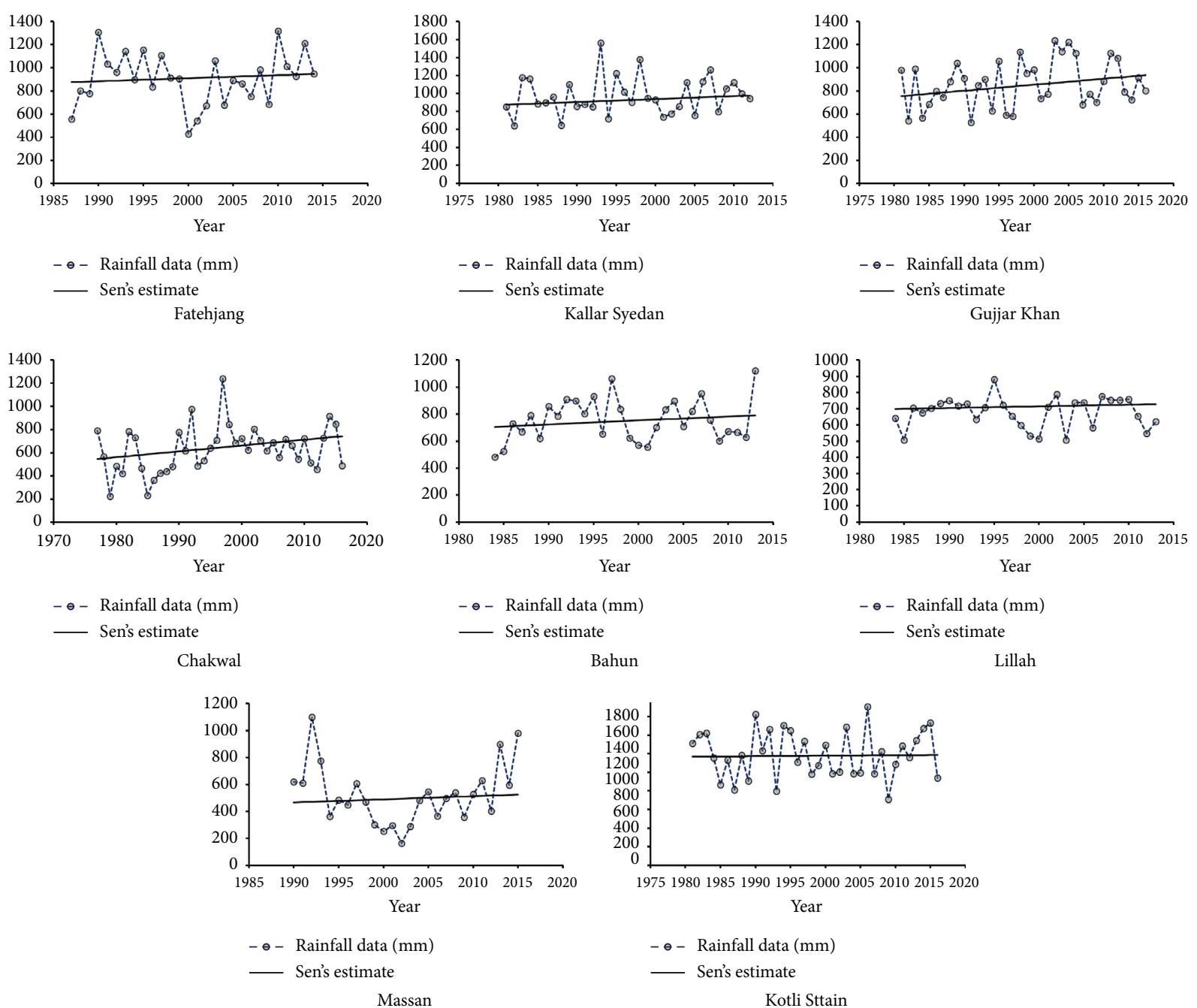

(b)

FIGURE 7: Temporal rainfall trend analysis of SRB rain gauge stations on an annual basis; (a) decreasing trend stations (Murree, Islamabad, NARC, and Rawalpindi stations belong to zone-1; Mangla and Jhelum belong to zone-2; Khewra and Talagang belong to zone-3); (b) increasing trend stations (Fatehjang, Kallar Syedan, and Gujjar Khan belong to zone-2; Chakwal, Bahun, Lillah, and Massan belong to zone3; Kotli Sattian belongs to zone-1). The scale of the figures is adjusted to the rainfall value.

Figure $8(\mathrm{c})$ shows the annual average rainfall distribution of the study area. Zone-1 northern part which includes Murree, Kotli Sattian, Islamabad, NARC, and Rawalpindi showed an annual precipitation frequency of approximately $>1000 \mathrm{~mm}$. The central part (zone-2) stations such as Fatehjang, Kallar Syedan, Gujjar Khan, Mangla, and Jhelum indicated precipitation frequencies of approximately 490-1000. The southern part (zone-3) stations such as Chakwal, Bahun, Talagang, and Massan receive annual rainfall between 275 and $492 \mathrm{~mm}$. Similarly, the entire Soan River Basin showed annual precipitation of approximately $275-1710 \mathrm{~mm}$. The spatial distribution of the annual station trends showed that most sites were characterized by nonsignificant positive and negative trends. MK test results showed an increase in the amount of precipitation at lowelevation stations, whereas a decrease in the amount of precipitation was noticed for higher-elevation stations.
4.4. Precipitation Ratio $(P R)$ and Monsoon Precipitation Index $(M P I)$. From the foregoing temporal and spatial distribution of rainfall over the Soan River Basin, it is seen that rainfall is highly variable in space and time. The abnormalities of rainfall at any location may be brought by a simple ratio of precipitation. It is the difference between the maximum and minimum annual rainfall divided by mean annual rainfall:

$$
P_{R}=\frac{\left(P_{\mathrm{Max}}-P_{\mathrm{Min}}\right)}{P_{\mathrm{MAR}}} \times 100
$$

where $P_{R}$ is the precipitation ratio, $P_{\mathrm{Max}}$ is the maximum mean annual rainfall, $P_{\text {Min }}$ is the minimum mean annual rainfall, and $P_{\mathrm{MAR}}$ is the mean annual rainfall.

This ratio gives the stability of rainfall with a spatial relationship. The higher the ratio, the higher the abnormality in rainfall and vice versa [84]. The precipitation ratio, i.e., 


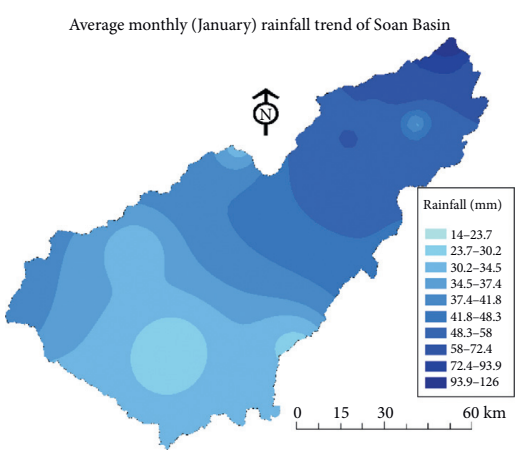

Average monthly (April) rainfall trend of Soan Basin

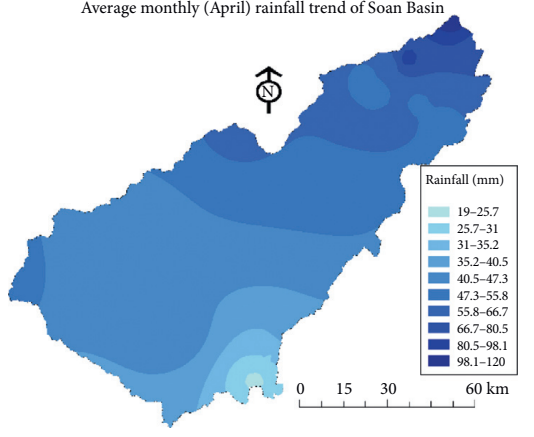

Average monthly (July) rainfall trend of Soan Basin
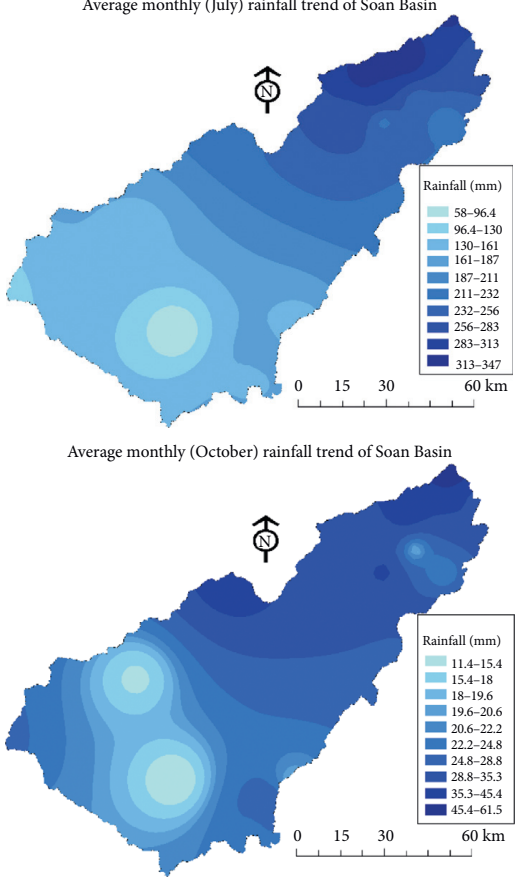

Average monthly (February) rainfall trend of Soan Basin

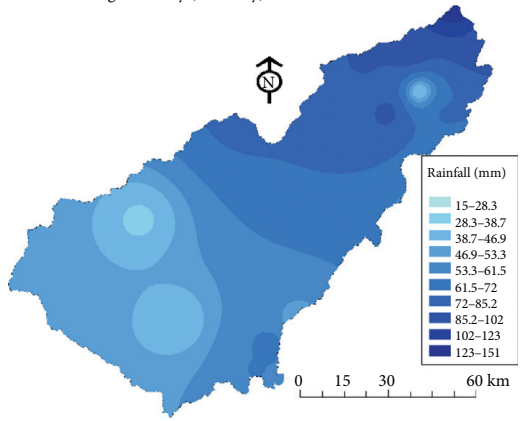

Average monthly (May) rainfall trend of Soan Basin

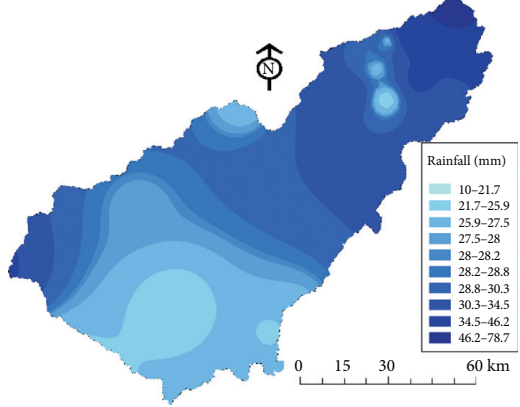

Average monthly (August) rainfall trend of Soan Basin

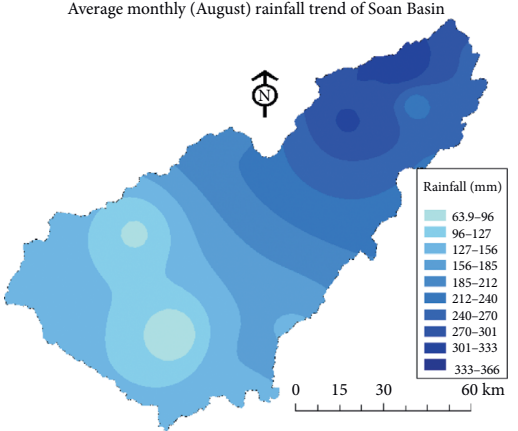

Average monthly (November) rainfall trend of Soan Basin

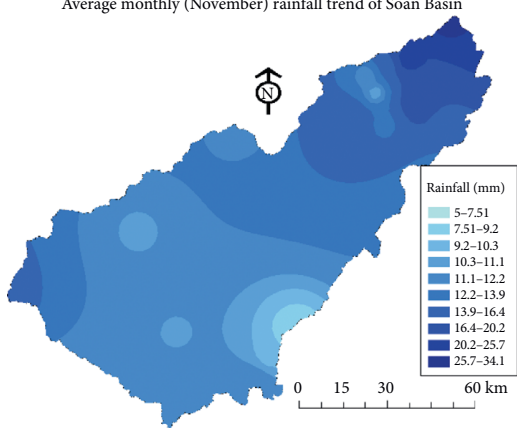

(a)

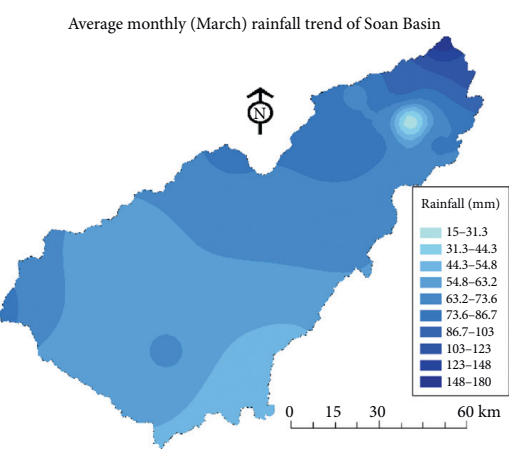

Average monthly (June) rainfall trend of Soan Basin

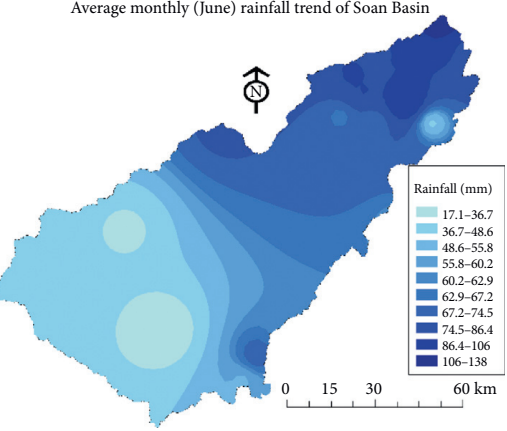

Average monthly (September) rainfall trend of Soan Basin

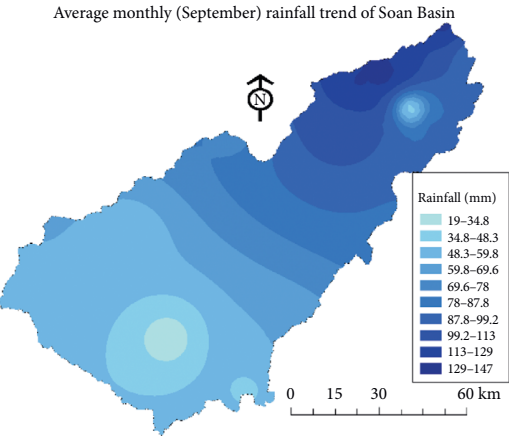

Average monthly (December) rainfall trend of Soan Basin

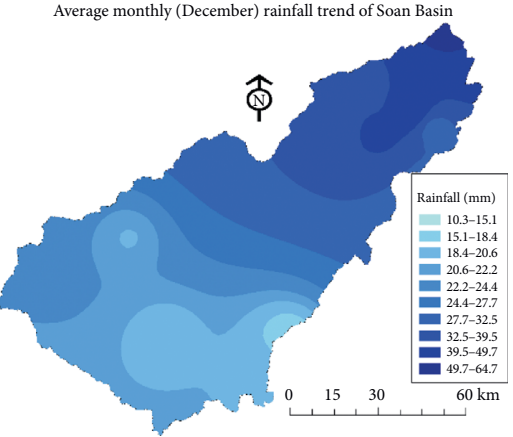

Figure 8: Continued. 

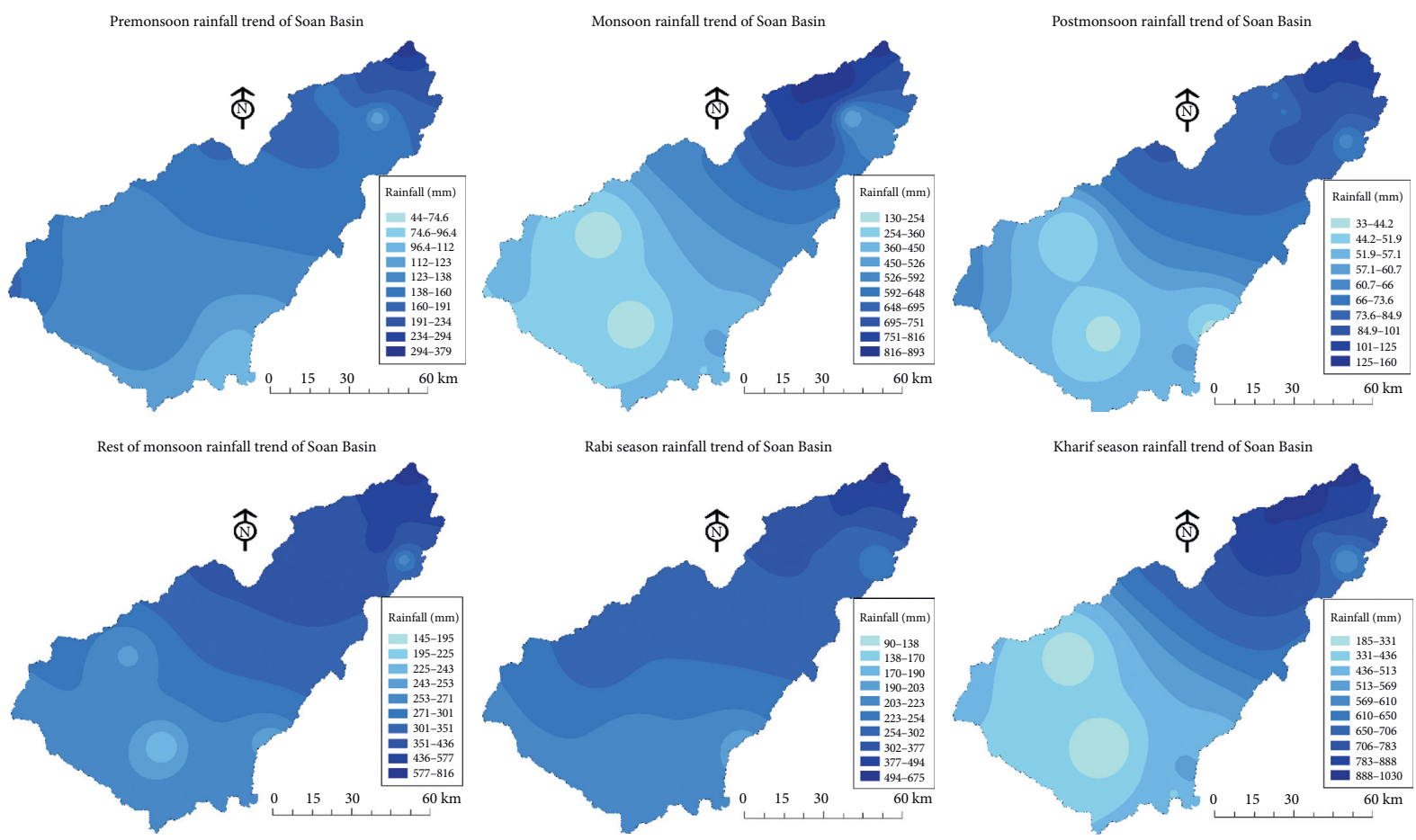

(b)

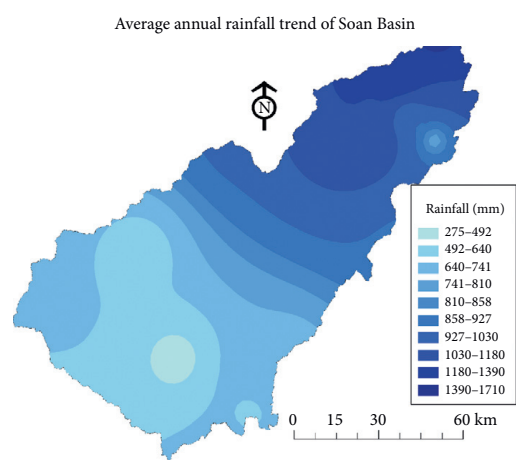

(c)

FIgURE 8: Spatial distribution of (a) monthly, (b) seasonal, and (c) annual rainfall over the study area.

maximum abnormality for annual rainfall ranged between 55 (Lillah) and 178 (Massan) as shown in Table 4. This is mostly associated with the topographic features and drought season. It was analyzed that half of the rain gauge stations (Islamabad, NARC, Rawalpindi, Fatehjang, Mangla, Chakwal, Talagang, and Massan) have shown high precipitation ratio during annual rainfall (>100), i.e., showing high abnormality. The three high-altitude stations (Islamabad, NARC, and Rawalpindi) have the same rainfall patterns and showed the same precipitation ratio. Chakwal, Talagang, and Massan stations showed the highest PR, indicating highest abnormality while these stations are in lowlands. Six rain gauge stations (Lillah, Murree, Gujjar Khan, Kotli Sattian, Bahun, and Khewra) have PR ratio less than 100 showing low abnormality.

Ashfaq et al. [85] defined the monsoon precipitation index (MPI) as the departure of rainfall from the climatological means. Calculation of MPI is useful for both agricultural and hydrological applications. Since MPI is not adversely affected by the topography, it gives an idea about spatial variation of monsoon rainfall over different topographical regions. The higher the MPI, the lesser the rainfall variation at the individual station. In the present study, based on monthly rainfall data, monsoon precipitation index (MPI) has been calculated using the following equation:

$$
\text { MPI }=\frac{\text { annual range }}{\text { total annual rainfall }}
$$

where annual range $=($ monsoon rainfall - nonmonsoon rainfall).

MPI in Soan Basin varied from -0.024 (Talagang) to 0.391 (NARC). The lowest MPI of -0.024 to 0.259 indicates drought conditions due to very less rainfall during the monsoon months. The high MPI of 0.293 to 0.391 indicates less rainfall variability as given in Table 6 . 
TABLE 6: Precipitation ratio and monsoon precipitation index of rainfall stations.

\begin{tabular}{lcc}
\hline Station & PR & MPI \\
\hline Murree & 67 & 0.037 \\
Kotli Sattian & 84 & 0.167 \\
Islamabad & 102 & 0.331 \\
NARC & 101 & 0.391 \\
Rawalpindi & 101 & 0.329 \\
Fatehjang & 98 & 0.259 \\
Kallar Syedan & 95 & 0.313 \\
Gujjar Khan & 82 & 0.321 \\
Mangla & 107 & 0.293 \\
Jhelum & 91 & 0.347 \\
Bahun & 85 & 0.332 \\
Chakwal & 157 & 0.216 \\
Khewra & 87 & 0.376 \\
Lillah & 55 & 0.304 \\
Talagang & 153 & -0.024 \\
Massan & 178 & 0.053 \\
\hline
\end{tabular}

\section{Conclusions and Recommendation}

The results of the study depicted that there is substantial year-to-year and season-to-season variability in rainfall patterns, and rainfall patterns are generally erratic in nature. The statistical results of the Mann-Kendall test and Sen's slope estimator highlighted that most of the rainfall stations in highland areas presented decreasing trends of rainfall on annual basis. The central and lowland stations of the study area recorded an increasing trend of rainfall except for Talagang station. The statistical analysis indicated that the average annual rainfall of the study area between $492 \mathrm{~mm}$ and $1710 \mathrm{~mm}$ in lowland and high-altitude areas, respectively. Rainfall is characterized by great seasonal variability. Of the whole year's rainfall, about 70 to $75 \%$ fall during the monsoon season. The monthly analysis indicated that July and August give the maximum amount of rainfall while November and December give a minimum amount of rainfall. Spatial distribution maps obtained using the IDW method through the GIS software revealed a wide range of rainfalls (for all seasons) through the basin, whereas many different zones of rainfalls could be recognized. According to the rainfall pattern of the study area, there is a lack of water during post-monsoon months and great differences in rainfall amounts between the mountainous areas and the lowlands. There is a need for the rational management of mountainous areas using mini and check dams to increase water production and stream regulation for lowland area water availability.

Overall, our study progresses scientific knowledge regarding spatial and temporal heterogeneity in rainfall of different zones of the Soan River Basin by using historical station data. The results provide preliminary and significant information of rainfall variability depending on the station elevations and zones. Normally, the northeast wind brings rain during winter, and the southeast wind brings monsoon rains in summer. But the pattern has changed because of what is believed to be global warming. Additionally, this study may prove significant to predict heterogeneity of rainfall trends for other regions in the world with similar meteorological conditions; this information could enable better agricultural management. Altogether, we found evidence of seasonal variations that could influence the water resources and agricultural sectors of the whole study region. Based on our analysis, we highly recommend further investigations to establish the cause of rainfall variations in high-altitude areas and to explore the relationship between temperature and precipitation at zonal and station levels across the elevation of Pothwar region, Pakistan.

\section{Data Availability}

The data used to support the finding of the study are available on special request.

\section{Conflicts of Interest}

The authors declare no conflicts of interest.

\section{Acknowledgments}

The authors acknowledge the Pakistan Meteorological Department (PMD) and Surface Water Hydrology ProjectWater and Power Development Authority (SWHPWAPDA) and Soil and Water Conservation Research Institute (SAWCRI) for the provision of rainfall data.

\section{References}

[1] IPCC, Global warming of $1.5^{\circ} \mathrm{C}$. An IPCC Special Report on the Impacts of Global Warming of $1.5^{\circ} \mathrm{C}$ above Pre-industrial Levels and Related Global Greenhouse Gas Emission Pathways, in the Context of Strengthening the Global Response to the Threat of Climate Change, Sustainable Development, and Efforts to Eradicate Poverty, V. Masson-Delmotte, P. Zhai, H.-O. Pörtner et al., Eds., 2018, In press.

[2] IPCC, Climate Change 2013: The Physical Science Basis. Contribution of Working Group I to the Fifth Assessment Report of the Intergovernmental Panel on Climate Change, T. F. Stocker, D. Qin, G.-K. Plattner et al., Eds., p. 1535, Cambridge University Press, Cambridge, UK, 2013.

[3] A. Malik, A. Kumar, P. Guhathakurta, and O. Kisi, "Spatialtemporal trend analysis of seasonal and annual rainfall (1966-2015) using innovative trend analysis method with significance test," Arabian Journal of Geosciences, vol. 12, no. 10, 2019.

[4] A. Bellu, L. F. Sanches Fernandes, R. M. V. Cortes, and F. A. L. Pacheco, "A framework model for the dimensioning and allocation of a detention basin system: the case of a floodprone mountainous watershed," Journal of Hydrology, vol. 533, pp. 567-580, 2016.

[5] D. P. S. Terêncio, L. F. Sanches Fernandes, R. M. V. Cortes, J. P. Moura, and F. A. L. Pacheco, "Rainwater harvesting in catchments for agro-forestry uses: a study focused on the balance between sustainability values and storage capacity," Science of the Total Environment, vol. 613, pp. 1079-1092, 2018.

[6] V. Kumar and S. K. Jain, "Rainfall trend in Ganga-Brahmputra-Meghna river basins of India (1951-2004)," Journal of Hydrology, vol. 33, pp. 59-66, 2010. 
[7] S. Wang, S. Jiao, and H. Xin, "Spatio-temporal characteristics of temperature and precipitation in Sichuan province, southwestern China, 1960-2009," Quaternary International, vol. 286, pp. 103-115, 2013.

[8] L. Cui, L. Wang, Z. Lai, Q. Tian, W. Liu, and J. Li, "Innovative trend analysis of annual and seasonal air temperature and rainfall in the Yangtze river basin, China during 1960-2015," Journal of Atmospheric and Solar-Terrestrial Physics, vol. 164, pp. 48-59, 2017.

[9] X. Chang, Z. Xu, G. Zhao, T. Cheng, and S. Song, "Spatial and temporal variations of precipitation during 1979-2015 in Jinan City, China," Journal of Water and Climate Change, vol. 9, no. 3, pp. 540-554, 2018.

[10] S. M. Pingale, D. Khare, M. K. Jat, and J. Adamowski, "Spatial and temporal trends of mean and extreme rainfall and temperature for the 33 urban centers of the arid and semi-arid state of Rajasthan, India," Atmospheric Research, vol. 138, pp. 73-90, 2014.

[11] Q. Z. Chaudhry, Climate Change Profile of Pakistan, Asian Development Bank, Manila, Philippines, 2017.

[12] Government of Pakistan, Framework for Implementation of Climate Change Policy, Climate Change Division Islamabad, Pakistan, 2013.

[13] Z. A. Sathar and K. Khan, Eds., Climate, Population, and Vulnerability in Pakistan: Exploring Evidence of Linkages for Adaptation, Population Council, Islamabad, Pakistan, 2019.

[14] A. Malik and A. Kumar, "Spatio-temporal trend analysis of rainfall using parametric and non-parametric tests: case study in Uttarakhand, India," Theoretical and Applied Climatology, vol. 140, no. 1, pp. 183-207, 2020.

[15] D. Jhajharia, Y. Dinpashoh, E. Kahya, R. R. Choudhary, and V. P. Singh, "Trends in temperature over Godavari river basin in southern peninsular India," International Journal of Climatology, vol. 34, no. 5, pp. 1369-1384, 2014.

[16] H. Tabari, B. S. Somee, and M. R. Zadeh, "Testing for longterm trends in climatic variables in Iran," Atmospheric Research, vol. 100, no. 1, pp. 132-140, 2011.

[17] B. S. Some'e, A. Ezani, and H. Tabari, "Spatiotemporal trends and change point of precipitation in Iran," Atmospheric Research, vol. 113, pp. 1-12, 2012.

[18] B. Amirataee, M. Montaseri, and H. Sanikhani, "The analysis of trend variations of reference evapotranspiration via eliminating the significance effect of all autocorrelation coefficients," Theoretical and Applied Climatology, vol. 126, no. 1-2, pp. 131-139, 2016.

[19] M. Hossain, K. Roy, and D. Datta, "Spatial and temporal variability of rainfall over the south-west coast of Bangladesh," Climate, vol. 2, no. 2, pp. 28-46, 2014.

[20] M. Ashraf and J. K. Routray, "Spatio-temporal characteristics of precipitation and drought in Balochistan province, Pakistan,” Natural Hazards, vol. 77, no. 1, pp. 229-254, 2015.

[21] R. Mahmood and S. Jia, "Spatial and temporal hydro-climatic trends in the transboundary Jhelum River basin," Journal of Water and Climate Change, vol. 8, no. 3, pp. 423-440, 2017.

[22] S. Ahmad, M. Israr, S. Liu et al., "Spatio-temporal trends in snow extent and their linkage to hydro-climatological and topographical factors in the Chitral river basin (Hindukush, Pakistan)," Geocarto International, vol. 35, no. 7, pp. 711-734, 2020.

[23] Z. Nawaz, L. Li, G. Chen, and Y. Guo, “Temporal and spatial characteristics of precipitation and temperature in Punjab, Pakistan," Water, vol. 11, no. 9, p. 1916, 2019.

[24] S. Ali, B. Khalid, R. S. Kiani et al., "Spatio-temporal variability of summer monsoon onset over Pakistan," Asia-Pacific
Journal of Atmospheric Sciences, vol. 56, no. 1, pp. 147-172, 2020.

[25] K. Khatiwada, J. Panthi, M. Shrestha, and S. Nepal, "Hydroclimatic variability in the Karnali river basin of Nepal Himalaya," Climate, vol. 4, no. 2, p. 17, 2016.

[26] D. N. D. Phuong, V. T. Linh, T. T. Nhat, H. M. Dung, and N. K. Loi, "Spatiotemporal variability of annual and seasonal rainfall time series in Ho Chi Minh City, Vietnam," Journal of Water and Climate Change, vol. 10, no. 3, pp. 658-670, 2019.

[27] M. Türkeş, T. Koç, and F. Sariş, "Spatiotemporal variability of precipitation total series over Turkey," International Journal of Climatology, vol. 29, no. 8, pp. 1056-1074, 2009.

[28] I. Dabanli, Z. Şen, M. Ö. Yeleğen, E. Şişman, B. Selek, and Y. S. Güçlü, "Trend assessment by the Innovative-Şen method," Water Resources Management, vol. 30, no. 14, pp. 5193-5203, 2016.

[29] H. Ouatiki, A. Boudhar, A. Ouhinou et al., "Trend analysis of rainfall and drought over the Oum Er-Rbia river basin in Morocco during 1970-2010," Arabian Journal of Geosciences, vol. 12, no. 4, 2019.

[30] T. Caloiero, R. Coscarelli, and E. Ferrari, "Application of the innovative trend analysis method for the trend analysis of rainfall anomalies in Southern Italy," Water Resources Management, vol. 32, no. 15, pp. 4971-4983, 2018.

[31] S. Chattopadhyay and D. Edwards, "Long-term trend analysis of precipitation and air temperature for Kentucky, United States," Climate, vol. 4, no. 1, p. 10, 2016.

[32] H. Birara, R. P. Pandey, and S. K. Mishra, "Trend and variability analysis of rainfall and temperature in the Tana basin region, Ethiopia," Journal of Water and Climate Change, vol. 9, no. 3, pp. 555-569, 2018.

[33] T. Kabanda, "Long-term rainfall trends over the Tanzania coast," Atmosphere, vol. 9, no. 4, p. 155, 2018.

[34] R. S. Bradley, H. F. Diaz, J. K. Eischeid, P. D. Jones, P. M. Kelly, and C. M. Goodess, "Precipitation fluctuations over northern hemisphere land areas since the mid-19th century," Science, vol. 237, no. 4811, pp. 171-175, 1987.

[35] H. F. Diaz, R. S. Bradley, and J. K. Eischeid, "Precipitation fluctuations over global land areas since the late 1800's," Journal of Geophysical Research, vol. 94, no. D1, p. 1195, 1989.

[36] M. Hulme, T. J. Osborn, and T. C. Johns, "Precipitation sensitivity to global warming: comparison of observations with HadCM2 simulations," Geophysical Research Letters, vol. 25, no. 17, pp. 3379-3382, 1998.

[37] P. Maheras, "Changes in precipitation conditions in the Western Mediterranean over the last century," Journal of Climatology, vol. 8, no. 2, pp. 179-189, 1988.

[38] B. Yu and D. T. Neil, "Long-term variations in regional rainfall in the south-west of Western Australia and the difference between average and high intensity rainfalls," International Journal of Climatology, vol. 13, no. 1, pp. 77-88, 1993.

[39] C. Rodriguez-Puebla, A. H. Encinas, S. Nieto, and J. Garmendia, "Spatial and temporal patterns of annual precipitation variability over the Iberian Peninsula," International Journal of Climatology, vol. 18, no. 3, pp. 299-316, 1998.

[40] S. Ullah, Q. You, W. Ullah, and A. Ali, "Observed changes in precipitation in China-Pakistan economic corridor during 1980-2016," Atmospheric Research, vol. 210, pp. 1-14, 2018.

[41] N. Khan, S. Shahid, T. b. Ismail, and X.-J. Wang, "Spatial distribution of unidirectional trends in temperature and temperature extremes in Pakistan," Theoretical and Applied Climatology, vol. 136, no. 3-4, pp. 899-913, 2019. 
[42] M. Qasim, S. Khlaid, and D. F. Shams, "Spatiotemporal variations and trends in minimum and maximum temperatures of Pakistan," Journal of Applied Environmental and Biological Sciences, vol. 4, pp. 85-93, 2014.

[43] M. Khattak, M. Babel, and M. Sharif, "Hydro-meteorological trends in the upper Indus river basin in Pakistan," Climate Research, vol. 46, no. 2, pp. 103-119, 2011.

[44] G. Rahman, Atta-ur-Rahman, Samiullah, and D. Muhammad, "Spatial and temporal variation of rainfall and drought in Khyber Pakhtunkhwa Province of Pakistan during 1971-2015," Arabian Journal of Geosciences, vol. 11, no. 46, 2018.

[45] I. Ahmad, D. Tang, T. Wang, M. Wang, and B. Wagan, "Precipitation trends over time using Mann-Kendall and Spearman's rho tests in Swat river basin, Pakistan," Advances in Meteorology, vol. 2015, pp. 1-15, 2015.

[46] K. Ahmed, S. Shahid, E. Chung, T. Ismail, and X. Wang, "Spatial distribution of secular trends in annual and seasonal precipitation over Pakistan,” Climate Research, vol. 74, no. 2, pp. 95-107, 2017.

[47] P. Reggiani, B. Mukhopadhyay, T. H. M. Rientjes, and A. Khan, "A joint analysis of river runoff and meteorological forcing in the Karakoram, upper Indus basin," Hydrological Processes, vol. 31, no. 2, pp. 409-430, 2017.

[48] M. Hanif, A. H. Khan, and S. Adnan, "Latitudinal precipitation characteristics and trends in Pakistan," Journal of Hydrology, vol. 492, pp. 266-272, 2013.

[49] M. S. Adnan and S. Lee, "Long-term variability and changes of the precipitation regime in Pakistan," Asia-Pacific Journal of Atmospheric Sciences, vol. 50, no. 3, pp. 271-282, 2014.

[50] S. Salma, S. Rehman, and M. A. Shah, "Rainfall trends in different climate zones of Pakistan," Pakistan Journal of Meteorology, vol. 9, no. 17, pp. 37-47, 2012.

[51] M. Ali Aun, A. Ghani, M. Azeem, M. Adnan, and M. Ahsan Latif, "Recognizing rainfall pattern for Pakistan using computational intelligence," International Journal of Advanced Computer Science and Applications, vol. 8, no. 11, pp. 487-491, 2017.

[52] F. Safdar, M. F. Khokhar, M. Arshad, and I. H. Adil, "Climate change indicators and spatiotemporal shift in monsoon patterns in Pakistan," Advances in Meteorology, vol. 2019, pp. 1-14, 2019.

[53] G. Naheed, D. H. Kazmi, and G. Rasul, "Seasonal variation of Rainy days in Pakistan," Pakistan Journal of Meteorology, vol. 9, no. 18, pp. 9-13, 2013.

[54] Q. Z. Chaudhry, A. Mahmood, G. Rasul, and M. Afzaal, Climate Change Indicators of Pakistan, Technical Report No. PMD 22/2009, Pakistan Meteorological Department, Islamabad, Pakistan, 2009.

[55] S. Ahmad, M. Shafique, and M. Z. Ikram, "Rainfall intensityrunoff relationship for small catchments in Pothwar plateau," Journal of Engineering and Applied Sciences, vol. 3, no. 2, pp. 37-44, 1984.

[56] F. Hussain, Impact of rainfall and landuse pattern on water and sediment yield in soan basin, M.Sc thesis, Centre of Excellence in Water Resources Engineering, Lahore, Pakistan, 2015.

[57] F. Hussain, G. Nabi, and M. W. Boota, "Rainfall trend analysis by using the Mann-Kendall test \& Sen's slope estimates: a case study of District Chakwal rain gage, Barani area," Science International, vol. 27, no. 4, pp. 3159-3165, 2015.

[58] G. Nabi, F. Hussain, R.-S. Wu, V. Nangia, and R. Bibi, "Microwatershed management for erosion control using soil and water conservation Structures and SWAT modeling," Water, vol. 12, no. 5, p. 1439, 2020.

[59] A. Ashraf, "Risk modeling of soil erosion under different land use and rainfall conditions in Soan river basin, sub-Himalayan region and mitigation options," Modeling Earth Systems and Environment, vol. 6, no. 1, pp. 417-428, 2020.

[60] J. M. Mitchell, Climatic Change, World Meteorological Organization, Geneva, Switzerland, 1966.

[61] U. Asmat, H. Athar, A. Nabeel, and M. Latif, "An AOGCM based assessment of interseasonal variability in Pakistan," Climate Dynamics, vol. 50, no. 1-2, pp. 349-373, 2018.

[62] N. U. Ain, M. Latif, K. Ullah et al., "Investigation of seasonal droughts and related large-scale atmospheric dynamics over the Potwar Plateau of Pakistan," Theoretical and Applied Climatology, vol. 140, no. 1-2, pp. 69-89, 2020.

[63] R. O. Gilbert, Statistical Methods for Environmental Pollution Monitoring, Van Nostrand Reinhold, New York, NY, USA, 1987.

[64] E. H. Isaaks and R. M. Srivastava, An Introduction to Applied Geostatistics, Oxford University Press, Oxford, UK, 1989.

[65] T. Partal, "Wavelet transform-based analysis of periodicities and trends of Sakarya basin (Turkey) streamflow data," River Research and Applications, vol. 26, no. 6, pp. 695-711, 2010.

[66] P. Sonali and D. Nagesh Kumar, "Review of trend detection methods and their application to detect temperature changes in India," Journal of Hydrology, vol. 476, pp. 212-227, 2013.

[67] M. Sayemuzzaman and M. K. Jha, "Seasonal and annual precipitation time series trend analysis in North Carolina, United States," Atmospheric Research, vol. 137, pp. 183-194, 2014.

[68] H. B. Mann, "Nonparametric tests against trend," Econometrica, vol. 13, no. 3, p. 245, 1945.

[69] M. G. Kendall, . Rank Correlation Measures; Charles Griffin Book Series, Oxford University Press, London, UK, 1975.

[70] P. Yang, J. Xia, Y. Zhang, and S. Hong, "Temporal and spatial variations of precipitation in Northwest China during 1960-2013," Atmospheric Research, vol. 183, pp. 283-295, 2017.

[71] Y. Chen, Y. Guan, G. Shao, and D. Zhang, "Investigating trends in streamflow and precipitation in Huangfuchuan basin with wavelet analysis and the Mann-Kendall test," Water, vol. 8, no. 3, p. 77, 2016.

[72] R. Zamani, R. Mirabbasi, S. Abdollahi, and D. Jhajharia, "Streamflow trend analysis by considering autocorrelation structure, long-term persistence, and Hurst coefficient in a semi-arid region of Iran," Theoretical and Applied Climatology, vol. 129, no. 1-2, pp. 33-45, 2017.

[73] S. A. Salman, S. Shahid, T. Ismail, E.-S. Chung, and A. M. AlAbadi, "Long-term trends in daily temperature extremes in Iraq," Atmospheric Research, vol. 198, pp. 97-107, 2017.

[74] Y. Hu, S. Maskey, S. Uhlenbrook, and H. Zhao, "Streamflow trends and climate linkages in the source region of the Yellow river, China," Hydrological Processes, vol. 25, no. 22, pp. 3399-3411, 2011.

[75] K. E. Kunkel, K. Andsager, and D. R. Easterling, "Long-term trends in extreme precipitation events over the conterminous United States and Canada," Journal of Climate, vol. 12, no. 8, pp. 2515-2527, 1999.

[76] P. K. Sen, "Estimates of the regression coefficient based on Kendall's Tau," Journal of the American Statistical Association, vol. 63, no. 324, pp. 1379-1389, 1968.

[77] C. Price, S. Michaelides, S. Pashiardis, and P. Alpert, "Long term changes in diurnal temperature range in Cyprus," Atmospheric Research, vol. 51, no. 2, pp. 85-98, 1999. 
[78] T. Yao, L. Thompson, W. Yang et al., "Different glacier status with atmospheric circulations in Tibetan plateau and surroundings," Nature Climate Change, vol. 2, no. 9, pp. 663-667, 2012.

[79] D. R. Easterling, "Maximum and minimum temperature trends for the Globe," Science, vol. 277, no. 5324, pp. 364-367, 1997.

[80] S. Thakuri, S. Dahal, D. Shrestha et al., "Elevation-dependent warming of maximum air temperature in Nepal during 1976-2015," Atmospheric Research, vol. 228, pp. 261-269, 2019.

[81] R. Talchabhadel, R. Karki, B. R. Thapa, M. Maharjan, and B. Parajuli, "Spatio-temporal variability of extreme precipitation in Nepal," International Journal of Climatology, vol. 38, no. 11, pp. 4296-4313, 2018.

[82] A. Dai, K. E. Trenberth, and T. R. Karl, "Effects of clouds, soil moisture, precipitation, and water vapor on diurnal temperature range," Journal of Climate, vol. 12, no. 8, pp. 2451-2473, 1999.

[83] F. Salerno, N. Guyennon, S. Thakuri et al., "Weak precipitation, warm winters and springs impact glaciers of south slopes of Mt. Everest (central Himalaya) in the last 2 decades (1994-2013)," The Cryosphere, vol. 9, no. 3, pp. 1229-1247, 2015.

[84] I. M. Rathod and S. Aruchamy, "Spatial analysis of rainfall variation in Coimbatore district Tamilnadu using GIS," International Journal of Geomatics and Geosciences, vol. 1, no. 2, pp. 106-118, 2010.

[85] M. Ashfaq, Y. Shi, W.-w. Tung et al., "Suppression of south Asian summer monsoon precipitation in the 21st century," Geophysical Research Letters, vol. 36, no. 1, p. 1704, 2009. 